\title{
LITHOLOGY AND GEOCHEMISTRY OF THE LATE GLACIAL AND HOLOCENE SEDIMENTS FROM GOSTYŃ LAKE (WESTERN POMERANIA, MYŚLIBÓRZ LAKELAND)
}

\author{
ANDRZE] KORZENIOWSKI ${ }^{1}$, DANIEL OKUPNY ${ }^{2}$, ADAM MICHCZYŃSKI ${ }^{3}$, \\ JOANNA SŁAWIŃSKA ${ }^{2}$, RYSZARD KRZYSZTOF BORÓWKA ${ }^{2}$
}

\begin{abstract}
Sediment geochemistry and lithology were studied in Gostyń Lake in the eastern part of the Myślibórz Lakeland (part of the Western Pomeranian Lake District). The research was undertaken because relatively shallow lake basins without ground supply contribute to the intensification of water circulation through evaporation. Late Glacial and Holocene phases in the evolution of Gostyń Lake were reconstructed based on selected geochemical indicators (Fe/Mn, $\mathrm{S} / \mathrm{Fe}, \mathrm{Na} / \mathrm{K}, \mathrm{Mg} / \mathrm{Ca}, \mathrm{Cu} / \mathrm{Zn}, \mathrm{Na}+\mathrm{K}+\mathrm{Mg} / \mathrm{Ca}$, $\mathrm{Fe} / \mathrm{Ca}$ ) as well as on the presence of human activity (Stone Age, Bronze Age, Early Iron Age and Roman Period). Also, the geochemical and archaeological data were correlated. Generally, the lithogeochemical composition variability in the Gostyń Lake deposits was found to be controlled by changes in: 1) the climate, related to the biogenic accumulation environment, 2) land cover in the Late Glacial and Holocene, and 3) human activities. Principal Component Analysis (PCA) revealed four major variable groups responsible for the changes: hydroclimatic variations which determined the type of sedimentary conditions during the Holocene climate optimum; changes in the organic matter provenance (along with conditions favouring sulphide precipitation); and denudation processes in the Gostyn Lake catchment. The methods used allowed the distribution of ancient settlement to be traced. Interpretation of the geochemical indicators $(\mathrm{Fe} / \mathrm{Mn}, \mathrm{Cu} / \mathrm{Zn}, \mathrm{S} / \mathrm{Fe}, \mathrm{Ca} / \mathrm{Fe})$ should involve many more factors which, in the relevant literature, are treated as measures of changes in redox conditions.
\end{abstract}

Key words: lakes, biogenic deposits, geochemistry, human impact, Holocene, western Poland

\section{Introduction}

Environmental reconstructions based on lake and peatland records often register changes on a regional scale, but local changes are driven by geological structure and lithology in the catchment, the morphology of the basin, the source of supply, and the catchment of surface and ground waters (Wojciechowski 2000; Błaszkiewicz 2007; Nowaczyk, Owsianny 2011; Płóciennik et al. 2015; Dietze et al. 2016; Okupny et al. 2016). Lake basins and peat bogs are important archives also of natural past geological and hydroclimatic evolution in the West Pomeranian Lake District (Jasnowski 1962; Borówka 1992; Latałowa 1992, 1999a; Malkiewicz, Tomaszewska 2009; Madeja 2012; Bloom 2015; Lamentowicz et al. 2015).
Shortly after the last ice sheet had melted, Western Pomerania was penetrated by Late Palaeolithic reindeer hunters. Indirect and direct traces of their activities, dated to $13,000-10,000 \mathrm{BP}$, were found in both the Polish and German parts of Pomerania, including the islands of Rügen, Wolin, Usedom and Chrząszczewska near Kamień Pomorski; recently, such traces have been discovered in the vicinity of Szczecin (Galiński 2015). There are also numerous traces of Mesolithic communities penetrating and colonising the Pomeranian environment, which was much more human-friendly during the first millennia of the Holocene (Galiński 1992). During the Late Palaeolithic and Mesolithic, anthropogenic environmental effects were negligible, as can be concluded from the lack of distinct changes in natural succession of vegetation in Western Pomerania found in palynological research at a number

\footnotetext{
${ }^{1}$ ul. Brzozowa 17, 66-416 Różanki, Poland.

${ }^{2}$ University of Szczecin, Institute of Marine and Environmental Sciences, ul. Mickiewicza 16, 70-383 Szczecin, Poland; e-mail: daniel.okupny@usz.edu.pl, ORCID:0000-0002-8836-6044, ORCID: 0000-0002-1708-2722, ORCID: 0000-0002$7232-3453$

${ }^{3}$ Silesian University of Technology, Institute of Physics - Centre for Science and Education, ul. Konarskiego 22B, 44-100 Gliwice, Poland; ORCID: 0000-0003-2795-6830
} 
of sites, including the lakes Kołczewo and Racze on Wolin Island (Latałowa 1992, 1999a, b), Lake Święte 22 near Stargard (Malkiewicz 2009), Lake Chojna (Krupiński 1991), Lake Kwiecko (Madeja 2012), Lake Zarańskie (Noryśkiewicz 2014) and Lake Racze (Bloom 2015).

Human impact on the environment was more distinct in the Neolithic. In palynology, it is visible as an increasing contribution of NAP grains, accompanied by a reduced contribution of that of elm (Ulmus sp.), which is indicative of the emergence of open areas, mainly pastures and arable land (Latałowa 1992, 1999a; Bloom 2015). Very numerous Neolithic archaeological sites have also been discovered and described in the area since the mid-19th century (Siuchniński 1969, 1972), including in particular the most abundant traces of intensive development of the Funnel Beaker Culture (FBC). Most probably, the most spectacular sepulchral and/or cultural constructions, such as the very numerous megaliths that occur most abundantly in the southern part of the Pyrzyce Plain (Siuchniński 1972; Kulczycka-Leciejewiczowa 1996) or the rondel at Nowe Objezierze near Moryn that is being explored at present (Czerniak et al. 2019; Pędziszewska et al. 2019) should be associated with the FBC. Of hundreds of megaliths identified by German authors in the Pyrzyce Plain in the late 18th and early 19th centuries (Chmielewski 1952), only a few have persisted until now and are occasionally identified at present from the analysis of aerial photographs (Matuszewska, Szydłowski 2012). Regardless of this, the area is often taken into consideration in the discussion of the FBC genesis (Matuszewska 2019).

Western Pomerania is also an area of very numerous finds dated to later archaeological periods: to the Bronze Age and Early Iron Age, as well as to the Roman Period and the Early Middle Ages. Some are visible as legible remains of open-settlement township constructions or burial sites (Godłowski 1984; Kowalski, Kozłowska-Skoczka 2009/2010; Kaczmarek 2018).

All these archaeological sites attest to an intensive use of the Western Pomeranian natural environment since at least about $6000-5000$ years BP. However, despite the abundance of archaeological evidence, the knowledge on the extent of environmental transformations in different parts of Western Pomerania in past ages is still far from complete. This gap should be bridged by multiproxy-based exploration of natural archives, such as, in particular, sediments of inland sedimentation basins, lakes and peat bogs. Initial studies have already been carried out on a micro-region scale
(Borówka 1992, 1994; Latałowa 1999a, b; Płaza et al. 2013/2015; Bloom 2015; Lamentowicz et al. 2019). The importance of such studies stems not only from their potential to assess changes in the vegetation cover, but also from the possibility to trace the effects of human activities on lacustrine and bog ecosystems; in addition, intensification of erosion-denudation processes as well as matter circulation can be followed at the scale of the sedimentation reservoir catchment.

The sites particularly useful for reconstructing climate changes and anthropogenic effects are sedimentation reservoirs subject to the evapotranspiration regime sensu Drwal (1973, 1974). Therefore, such sedimentation basins in recently glaciated areas have been targeted many times in studies aimed at assessing lacustrine responses to Late Glacial and Holocene changes in climate and human impact (Borówka 1990, 1994; Hulisz et al. 2012; Karasiewicz et al. 2014a, 2017; Mendyk et al. 2016).

This paper is aimed at presenting initial results of palaeo-environmental studies on lacustrine sediments of Gostyń Lake near Barlinek, in particular addressing changes in the sediment lithology and geochemistry on the geological time scale. Particular attention is paid to assessing human impact on the evolution of this sedimentation basin in the context of archaeological research carried out within the framework of the Polish National Record of Archaeological Sites (Pol. AZP - Archeologiczne Zdjęcie Polski).

\section{Site description and coring}

Gostyń Lake ( $\varphi 53^{\circ} 00^{\prime} 13^{\prime \prime} \mathrm{N} ; \lambda 1^{\circ} 09^{\prime} 00^{\prime \prime} \mathrm{E}$; $\mathrm{H}-82.1 \mathrm{~m}$ a.s.1.) is located on a morainic upland of the Myślibórz Lakeland, about $4.6 \mathrm{~km} \mathrm{NW}$ of the centre of the town of Barlinek. Locally, lakes occupy up to $10 \%$ of the area (Fig. 1A). Gostyń Lake is a drainless morainic reservoir; its $7.8 \mathrm{~km}^{2}$ catchment lies on an undulating morainic upland rising to 85-95 $\mathrm{m}$ a.s.l. and built by layers of Vistulian and Warthian glacial till up to $20 \mathrm{~m}$ thick (Sochan, Piotrowski 2004; Piotrowski, Sochan 2011). The Gostyń Lake basin, $940 \times 500 \mathrm{~m}$ and 21.25 ha in size, is irregular, being wider in its northern part and narrowing to the south (Fig. 1B). Thus, the present surface area of the lake is three times larger than the mean size of drainless lakes calculated by Majdanowski (1950/51) for the River Oder catchment. The lake features three small islets, as well as submerged shallows vegetated by the common reed (Phragmites australis), bulrush (Typha latifolia), 
and common club-rush (Schoenoplectus lacustris). The mean and maximum depth of Gostyn are 1.5 and about $3.4 \mathrm{~m}$, respectively. According to the most recent classification of lakes (Solheim et al.
2019), the lake belongs to the group of lowland mixed and unstratified water body, which are fairly rare in Europe.

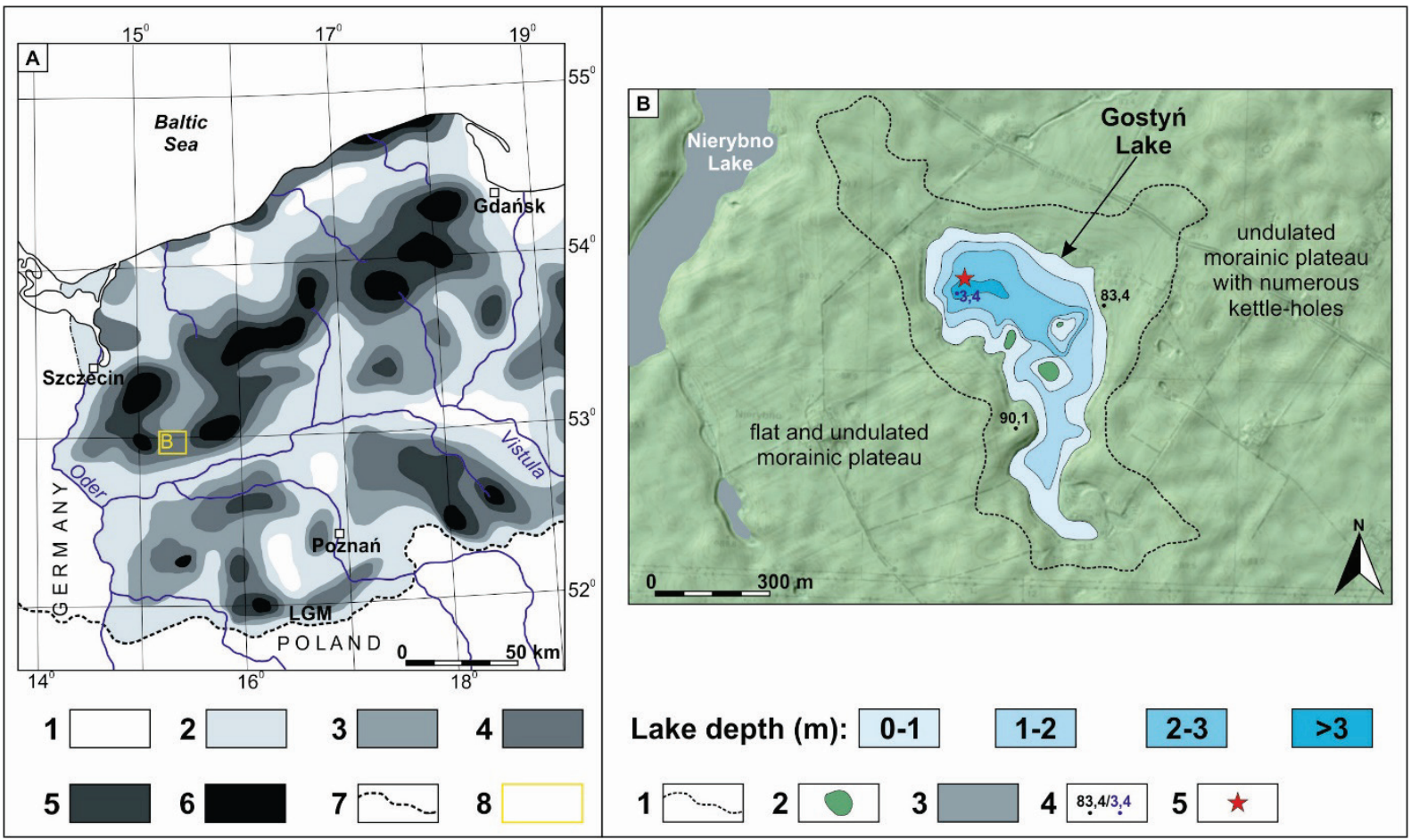

Fig. 1. Location of Gostyń Lake

A. Per cent contribution of lakes to the surface area of northern Poland after Majdanowski (1950/51)

1 - below $0.1 \%, 2$ - to $1 \%, 3$ - to $2 \%, 4$ - to $3 \%, 5$ - to 5\%,6 - to $10 \%, 7$ - boundaries of the Last Glacial Maximum after Marks (2005), 8 - study area

B. Digital elevation of the catchment (based on LiDAR data), lake bathymetry and geomorphology of the surrounding area

1 - Gostyń Lake catchment boundary, 2 - islands; 3 - other lakes, 4 - maximum, minimum altitudes and maximum depth, 5 - coring site (GOS 1)

The small catchment of Gostyń Lake is located in an area with a low mean annual precipitation not exceeding $550 \mathrm{~mm}$ (Koźmiński et al. 2012). The growing season (April-September) is characterised by a precipitation deficit averaging 130-150 mm (Kołodziej 2008), the deficiency being alleviated, albeit in part only, by precipitation in autumn-winter. The persistence of the lake attests to the importance of water retention by the soil and supply from subsurface resources. The lake is flanked to the west, south and east by steep, though not particularly high (up to $1.5 \mathrm{~m}$ ), escarpments supporting arable land, the northern shores being low-lying. To the north, west and south, the lake is surrounded by a wide rush belt which also connects the islets with the shores. The southern shallow embayment is almost entirely vegetated by yellow water lily communities. As shown by recent studies, changes in water level - like in other lakes in the northern part of Poland - are controlled primarily by local factors, with climatic effects playing a lesser role (Choiński et al. 2020). The results of archaeological study confirm the occurrence of many relicts in this area. In the area of 25 $\mathrm{km}^{2}$ surrounding Gostyń Lake, 24 archaeological sites (with 54 archaeological factors) have been registered. Half of them date to Prehistory (mainly the Stone Age and Roman Period), and only one to the Medieval Period (Figs 2, 3). 


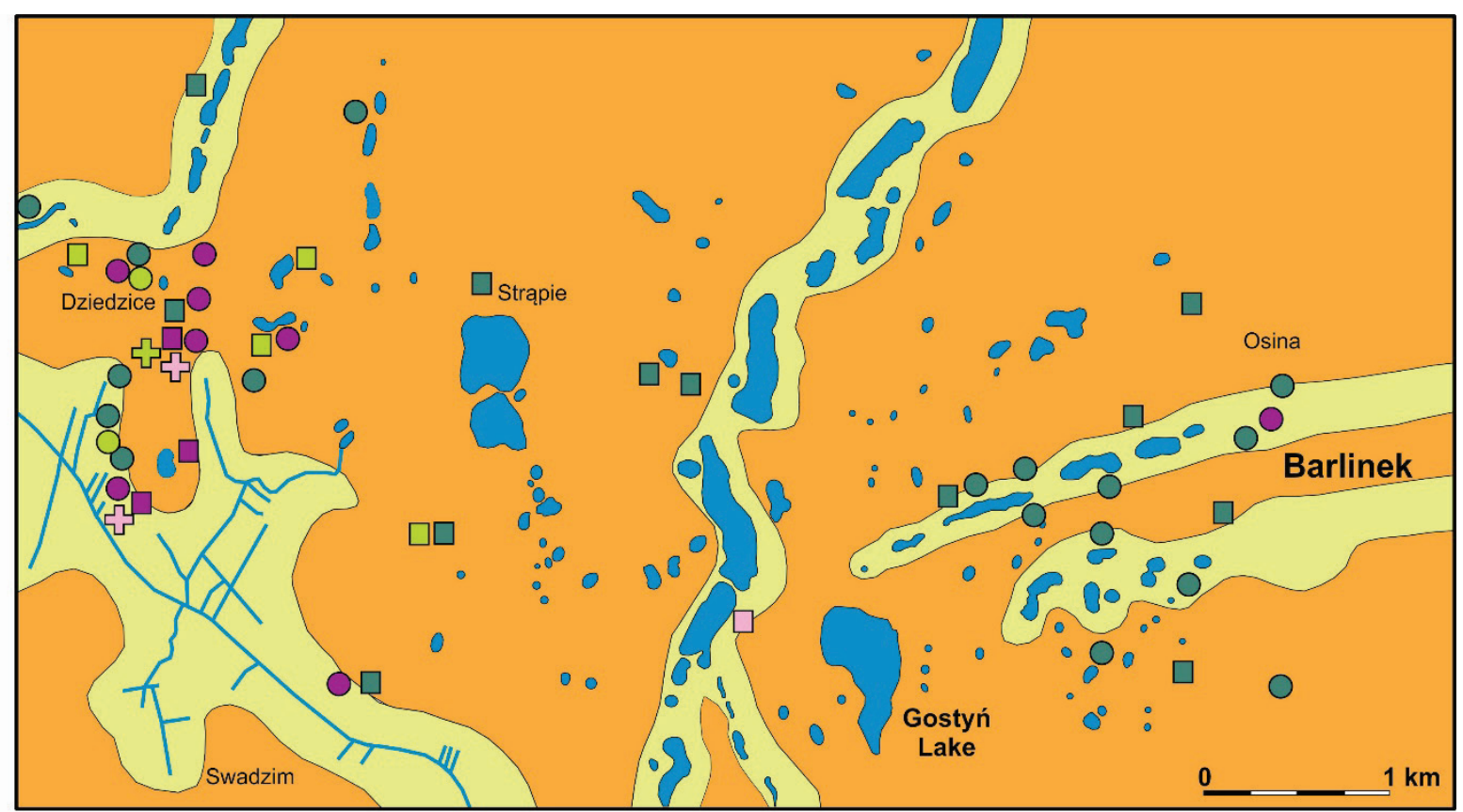

1

\section{$2 \circlearrowleft 3$ SE $\square$ aOb BA $\square$ a Ob ßc}

IA $\square a O b$ ß $A P \square a O b$

Fig. 2. Location of Prehistoric archaeological sites in the vicinity of Gostyń Lake after Kot (2013)

1 - morainic plateaus; 2 - tunnel valley bottom and water-logged meltwater depressions; 3 - lakes and streams; chronology of archaeological sites: SE - Stone Age, BA - Bronze Age, IA - Early Iron Age, AP - Roman Period; a - settlements; b - settlement traces; $\mathrm{c}$ - burial grounds
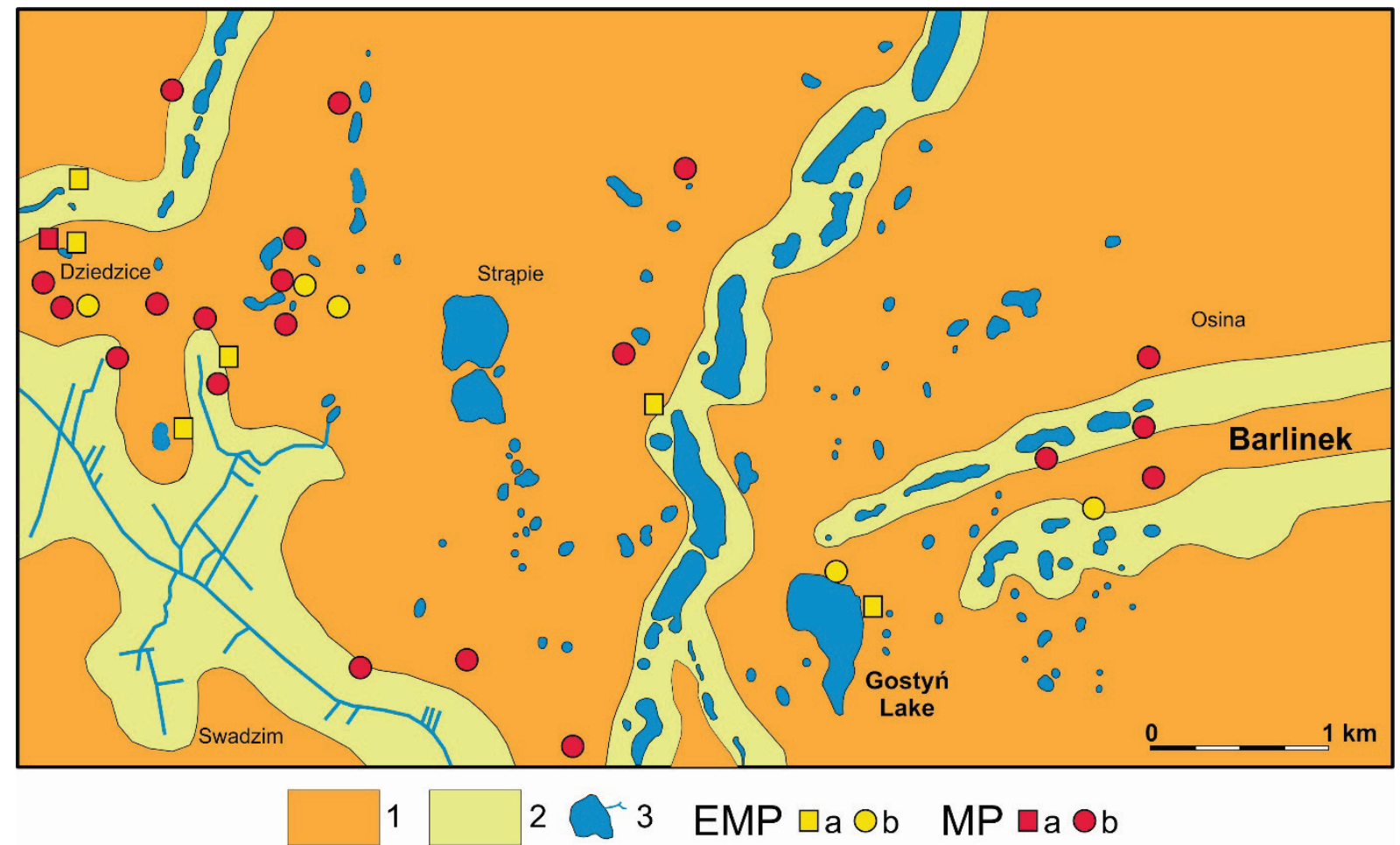

Fig. 3. Location of Medieval archaeological sites in the vicinity of Gostyń Lake after Kot (2013)

1 - morainic plateaus; 2 - tunnel valley bottom and water-logged meltwater depressions; 3 - lakes and streams; chronology of archaeological sites: EMP - Early Medieval Period, MP - Medieval Period; a - settlements, b - settlement traces 


\section{Methods}

\section{Field work}

The sediment core was collected in the north of the lake, in the deepest area (Fig. 1). The field work was conducted in winter, whereby individual core segments could be collected from ice. The core segments were collected with a 10 -cm-diameter, 50-cm-long Instorf corer. As opposed to tube corers, the Instorf corer does not compress sediment layers, and a $0.5-\mathrm{m}$-long half-cylinder core is retrieved undisturbed from the sediment. Following collection, each 0.5 -m-long sediment segment was placed in a plastic trough and wrapped tightly with sheets of plastic to prevent desiccation. In the laboratory, the segments were divided into about 5 -cm-long sections, with reference to lithological boundaries. Core GOS 1 (895 cm total length) yielded 179 samples.

\section{Sample preparation and laboratory analyses}

\section{Geochemistry}

Individual samples were freeze-dried in a Beta 1-8 LD plus lyophiliser by Christ. Following sediment homogenisation, about 2-g sediment samples dried at $105^{\circ} \mathrm{C}$ were analysed for loss on ignition (LOI) at $550{ }^{\circ} \mathrm{C}$ to calculate percentage contributions of organic and mineral matter (Heiri et al. 2001). The ash remaining from combustion, devoid of organic matter, was dissolved in a Speedwave microwave mineraliser (Berghof) in $8 \mathrm{ml}$ concentrated nitric acid, $2 \mathrm{ml} \mathrm{10 \%} \mathrm{hydrochloric}$ acid and $2 \mathrm{ml}$ peroxide. The solution was assayed using atomic absorption spectrometry in an AAS SOLARR 969 spectrometer (Unicam), for contents of $\mathrm{Na}, \mathrm{K}, \mathrm{Ca}, \mathrm{Mg}, \mathrm{Fe}, \mathrm{Mn}, \mathrm{Cu}, \mathrm{Zn}$ and $\mathrm{Pb}$.
Results were referred to $1 \mathrm{~g}$ sediment dry weight (d.w.). Air-dried sediment samples were analysed for contents of total carbon, total nitrogen, and total sulphur in a VARIOMAX CNS (Elementar). All the assays were performed at the Geochemical Laboratory, Institute of Marine and Environmental Sciences, University of Szczecin.

\section{$\underline{\text { Radiocarbon dating }}$}

To develop the chronology of the sediments of the Gostyń Lake, five bulk samples were radiocarbon-dated using the liquid scintillation counting technique (LSC). All the samples were processed according to a standard protocol (Tudyka et al. 2015). The dates were calibrated with the calibration software OxCal 4.2 (Bronk Ramsey et al. 2010) using the IntCal13 calibration curve (Reimer et al. 2013).

\section{$\underline{\text { Data visualisation and quantitative analysis }}$}

The data were processed using Microsoft Office Excel and PAST (Hammer et al. 2001) software; the latter was used to identify geochemical zones and to perform the Principal Components Analysis (PCA) to identify the major factors controlling changes in the sediment chemistry. The data were visualised using C2 graphic software (Juggins 2007) and CorelDRAW Graphics Suite X3.

\section{Results}

\section{$\underline{\text { Lithology }}$}

In the study profile, the bog series overlies lacustrine deposits that show an up-core gradation from silt gyttja at the bottom, through algal gyttja, to coarse-detritus gyttja. The bog deposits are overlain mostly by fine-detritus gyttja (Table 1).

Table 1

Core GOS 1 sediment lithology

\begin{tabular}{|l|l|}
\hline Depth (m) & \multicolumn{1}{|c|}{ Lithology } \\
\hline $0.00-0.40$ & fine-detritus gyttja, olive in colour \\
\hline $0.40-1.20$ & detritus (occasionally coarse-detritus) gyttja, grey-brown in colour \\
\hline $1.20-3.03$ & fine-detritus gyttja, olive in colour \\
\hline $3.03-5.80$ & moss peat, dark-brown in colour \\
\hline $5.80-6.10$ & sedge peat, dark-brown in colour \\
\hline $6.10-6.40$ & coarse-detritus gyttja, olive in colour \\
\hline $6.40-8.45$ & algal gyttja, occasionally with admixtures of sand and silt, olive in colour \\
\hline $8.45-8.95$ & silt gyttja, grey-olive in colour \\
\hline
\end{tabular}




\section{Core chronology}

To follow the temporal evolution of the Gostyn Lake deposits, a radiocarbon dating-based agedepth model was developed using the OxCal v4.3.2 software (Bronk Ramsey, Lee 2013), for core GOS 1 . The IntCal 13 calibration curve was used to calibrate the datings. The model was constructed using the PSequence command with $\mathrm{k}=0.5$. The model was based on five radiocarbon datings determined at the Gliwice laboratory (Table 2) and a single dating, for the core surface, referring to the coring date. The model fit was $96 \%$, evidencing the correctness of the assumptions. The timeframe produced by the model extends from the Younger Dryas to the present. The model is shown in Fig. 4.

\section{Geochemistry}

The geochemistry of the GOS 1 sediment profile is shown in Figs 5 and 6; the y axis represents the calibrated years b2k from the age-depth model. Local geochemical zones were identified with cluster analysis, with due consideration to the stratigraphic position of the samples. The analysis was performed with the following geochemical variables: LOI (a measure of the organic matter concentration), selected macro- and microelements (Na, $\mathrm{K}, \mathrm{Ca}, \mathrm{Mg}, \mathrm{Fe}, \mathrm{Mn}, \mathrm{Cu}, \mathrm{Zn}, \mathrm{Pb}$ ), and biogenic elements $(\mathrm{C}, \mathrm{N}$ and $\mathrm{S})$.

The results of the analysis produced five major geochemical zones (GZ I - GZ V); moreover, zones GZ I, GZ III and GZ IV could be subdivided into two sub-zones each (Figs 5, 6). The age and geochemical properties of the zones are described in Table 3.

\section{Data interpretation and discussion}

\section{Factors controlling sediment chemistry}

The PCA reduced the original 13 geochemical variables to four major components that, taken together, explained $88 \%$ of total data variance (Table 4). The PC1 axis (Fig. 7), which explained more than $50 \%$ of the total variance, is strongly positively correlated with the lithophile elements $(\mathrm{Na}$, $\mathrm{K}, \mathrm{Mg}, \mathrm{Fe}$ ), and negatively correlated with the organic matter, $\mathrm{C}, \mathrm{N}$. and Ca. It informs primarily on lithological differences in the sediments, as well as on changes in the mechanical denudation intensity (positive value), in contrast to the organic matter accumulation and chemical denudation (negative values). The available literature (Dean 1993; Koinig et al. 2003; Rydelek 2011; Woszczyk 2011) interprets lithophile components as proxies of denudation intensity, as they are supplied to lakes passively, in crystalline structures of quartz and aluminosilicates or as ions adsorbed on clayey minerals. The good agreement between changes in the relative extent of mechanical denudation in the Gostyń Lake catchment and the geochemical record in other biogenic accumulation reservoirs in the Polish Lowland (Okupny et al. 2013; Pleskot et al. 2018; Karasiewicz 2019) may be regarded as supporting the identification of post-glacial changes in the vegetation cover and land use. However, there is also evidence (Borówka 1992; Selvaray et al. 2016) that the accuracy and temporal resolution of the results may depend on the biogenic sediment accumulation rate.

Results of ${ }^{14} \mathrm{C}$ dating of Gostyń Lake sediment bulk samples

\begin{tabular}{|c|c|c|c|c|}
\hline $\begin{array}{c}\text { Depth } \\
(\mathrm{m})\end{array}$ & Material dated & Sample No. & $\begin{array}{c}{ }^{14} \mathrm{C} \text { age } \\
(\mathrm{yrs} \text { BP })\end{array}$ & $\begin{array}{c}\text { Calibrated age range } \\
\text { BP 95.4\% }\end{array}$ \\
\hline $1.35-1.40$ & $\begin{array}{c}\text { fine-detritus } \\
\text { gyttja }\end{array}$ & GdS-4068 & $1,845 \pm 85$ & $1,970-1,560$ \\
\hline $2.95-3.03$ & $\begin{array}{c}\text { fine-detritus } \\
\text { gyttja }\end{array}$ & GdS-4011 & $4,095 \pm 95$ & $4,855-4,355$ \\
\hline $4.85-4.90$ & moss peat & GdS-4022 & $5,470 \pm 80$ & $6,415-6,005$ \\
\hline $6.20-6.25$ & $\begin{array}{c}\text { coarse-detritus } \\
\text { gyttja }\end{array}$ & GdS-4016 & $6,290 \pm 75$ & $7,420-7,005$ \\
\hline $8.70-8.75$ & silt gyttja & GdS-4063 & $10,460 \pm 100$ & $12,650-12,030$ \\
\hline
\end{tabular}




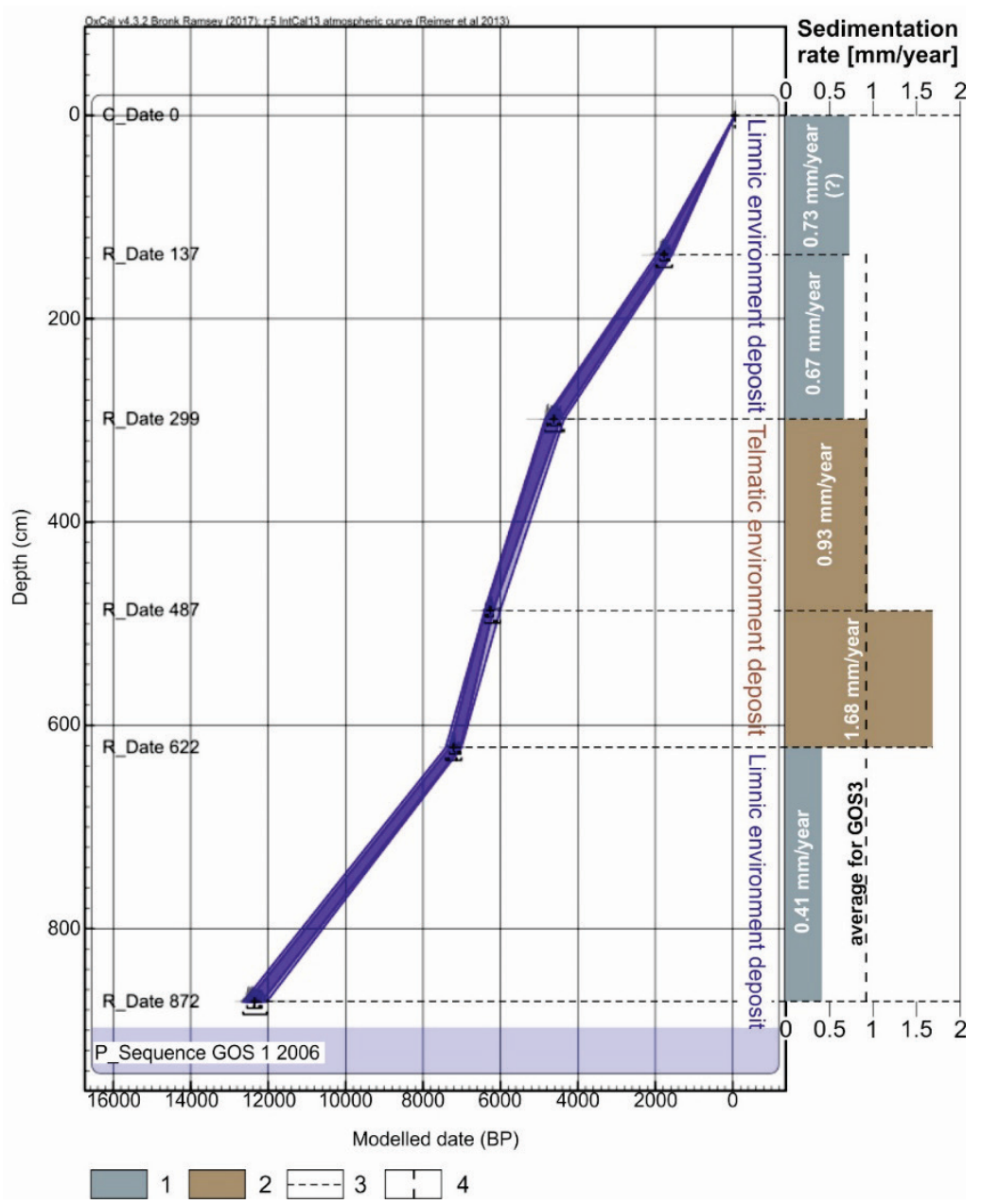

Fig. 4. Age-depth model of the GOS 1 profile from Gostyń Lake

1 - lake sediments, 2 - peat sediments, 3 - average sedimentation rate for selected sections, 4 - average sedimentation rate for all core

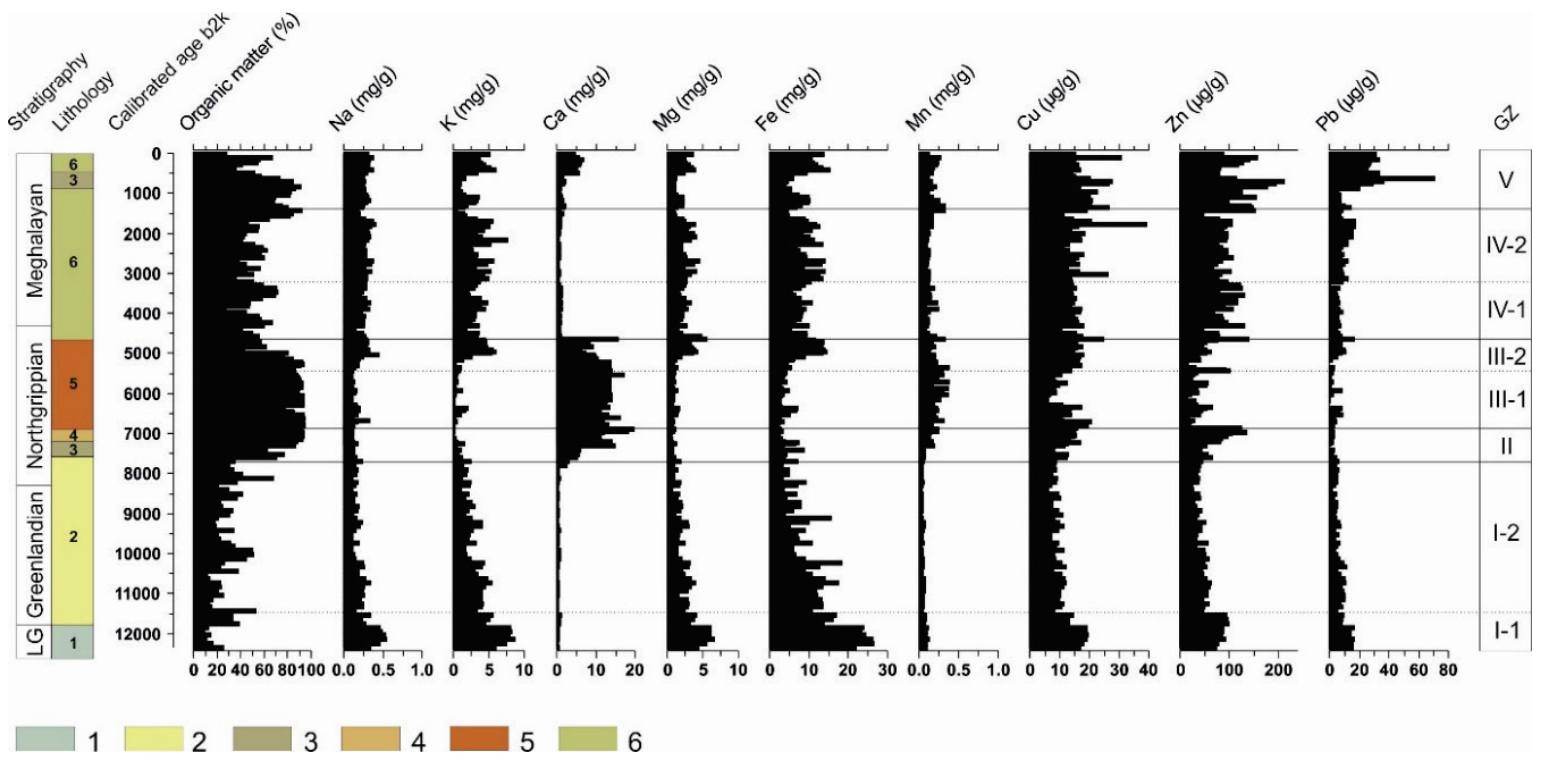

Fig. 5. Core GOS 1. Stratigraphic variability of organic matter concentration and contents of selected major and trace elements

1 - silt gyttja, 2 - algal gyttja, 3 - coarse-detritus gyttja, 4 - sedge peat, 5 - moss peat, 6 - fine-detritus gyttja; GZ - geochemical zones and sub-zones 
Detailed description of geochemical characteristics of sediments within identified geochemical zones and sub-zones

\begin{tabular}{|c|c|c|}
\hline $\begin{array}{c}\text { Geochemical } \\
\text { zone } \\
\text { and sub-zone }\end{array}$ & $\begin{array}{c}\text { Depth }(\mathrm{m}) \\
\text { Age (years b2k) }\end{array}$ & Description \\
\hline GZ I-1 & $\begin{array}{c}8.80-8.40 \\
\sim 12,300-11,500\end{array}$ & $\begin{array}{l}\text { Representing silt gyttja accumulation phase, at the transition of the Younger } \\
\text { Dryas to the Holocene; maximum contents of lithophile elements }(\mathrm{Na}, \mathrm{K}, \mathrm{Mg} \text { and } \\
\mathrm{Fe} \text {; higher contents of } \mathrm{Mn}, \mathrm{Cu}, \mathrm{Zn} \text { and } \mathrm{Pb} \text { than those in } \mathrm{GZ} \mathrm{I-2} \text {; substantial con- } \\
\text { tributions of } \mathrm{OM} \text { and biogenic elements }(\mathrm{C}, \mathrm{N} \text { and } \mathrm{S}) \text {; maximum values of me- } \\
\text { chanical denudation intensity indicators }(\mathrm{Mg} / \mathrm{Ca} \text { and } \mathrm{Na}+\mathrm{K}+\mathrm{Mg} / \mathrm{Ca} \text { ). }\end{array}$ \\
\hline GZ I-2 & $\begin{array}{c}8.40-6.45 \\
\sim 11,500-7650\end{array}$ & $\begin{array}{l}\text { Representing algal gyttja accumulation phase, with occasional admixtures of } \\
\text { sand and silt; characteristic but relatively low contents of } \mathrm{OM} \text {, total carbon and } \\
\text { total nitrogen, at a somewhat elevated concentration of total sulphur; gradual re- } \\
\text { duction in lithophile elements }(\mathrm{Na}, \mathrm{K}, \mathrm{Mg} \text { and } \mathrm{Fe}) \text {; stable but relatively low con- } \\
\text { tents of } \mathrm{Ca}, \mathrm{Mn}, \mathrm{Cu}, \mathrm{Zn} \text { and } \mathrm{Pb} \text {; distinct tendency towards reduction of mechani- } \\
\text { cal denudation indicators }(\mathrm{Mg} / \mathrm{Ca} \text { and } \mathrm{Na}+\mathrm{K}+\mathrm{Mg} / \mathrm{Ca}) \text { and } \mathrm{Fe} / \mathrm{Mn} \text { ratio. }\end{array}$ \\
\hline GZ II & $\begin{array}{c}6.45-5.70 \\
\sim 7,650-6,850\end{array}$ & $\begin{array}{l}\text { Representing accumulation of coarse-detritus gyttja and sedge peat. Rapid in- } \\
\text { crease in contents of } \mathrm{OM} \text { and biogenic elements (particularly sulphur). Increased } \\
\text { contents of } \mathrm{Ca}, \mathrm{Mn}, \mathrm{Cu} \text { and } \mathrm{Zn} \text {, accompanied by declining content of potassium } \\
\text { as well as fairly stable but low contents of } \mathrm{Na}, \mathrm{Mg}, \mathrm{Fe} \text { and } \mathrm{Pb} \text {. Increased values } \\
\text { of chemical denudation indicators }(\mathrm{Na} / \mathrm{K} \text { and } \mathrm{Ca} / \mathrm{Mg} \text { ratios) and almost negligi- } \\
\text { ble indicators of mechanical denudation. Distinct reduction of } \mathrm{Fe} / \mathrm{Mn} \text { and in- } \\
\text { creased } \mathrm{C} / \mathrm{N} \text { ratio. }\end{array}$ \\
\hline GZ III-1 & $\begin{array}{c}5.70-4.00 \\
\sim 6850-5450\end{array}$ & $\begin{array}{l}\text { Coinciding with moss peat accumulation phase. Highest contents of OM (up to } \\
\text { about } 90 \% \text { ) and total carbon. Variable but fairly high concentration of total nitro- } \\
\text { gen (3-4\%) and fairly stable concentration of sulphur (to about } 0.5 \% \text { ). Relatively } \\
\text { high and fairly stable content of } \mathrm{Ca}(\text { about } 15 \mathrm{mg} / \mathrm{g} \text { ) and gradually increasing } \\
\text { content of } \mathrm{Mn} \text { (from } 0.2 \text { to } 0.4 \mathrm{mg} / \mathrm{g} \text { ). Low contents of lithophile elements (Na, } \\
\mathrm{K}, \mathrm{Mg} \text { and } \mathrm{Fe} \text { ) and } \mathrm{Pb} \text {. Variable contents of } \mathrm{Cu} \text { and } \mathrm{Zn} \text {. High but declining val- } \\
\text { ues of chemical denudation indicators }(\mathrm{Na} / \mathrm{K} \text { and } \mathrm{Ca} / \mathrm{Mg} \text { ratios) as well as low } \\
\text { but stable values of mechanical denudation indicators }(\mathrm{Mg} / \mathrm{Ca} \text { and } \\
\mathrm{Na}+\mathrm{K}+\mathrm{Mg} / \mathrm{Ca} \text { ) and } \mathrm{Fe} / \mathrm{Mn} \text {. C/N ratio fluctuating from about } 15 \text { to } 22 \text {. }\end{array}$ \\
\hline GZ III-2 & $\begin{array}{c}4.00-3.03 \\
\sim 5,450-4,650\end{array}$ & $\begin{array}{l}\text { Representing the uppermost layer of moss peat. Reduction in OM concentration } \\
\text { (from } 90 \text { to } 50 \% \text { ), in contents of biogenic elements }(\mathrm{C}, \mathrm{N}, \mathrm{S}) \text { as well as } \mathrm{Ca} \text { and } \\
\mathrm{Mn} \text {. Distinct increase in contents of lithophile elements }(\mathrm{Na}, \mathrm{K}, \mathrm{Mg} \text { and } \mathrm{Fe}) \text { as } \\
\text { well as } \mathrm{Cu}, \mathrm{Zn} \text { and } \mathrm{Pb} \text {. Distinct reduction in values of chemical denudation indi- } \\
\text { cators }(\mathrm{Na} / \mathrm{K} \text { and } \mathrm{Ca} / \mathrm{Mg} \text { ratios) at a slight increase in mechanical denudation } \\
\text { ones }(\mathrm{Mg} / \mathrm{Ca} \text { and } \mathrm{Na}+\mathrm{K}+\mathrm{Mg} / \mathrm{Ca} \text { ) and } \mathrm{Fe} / \mathrm{Mn} \text {. Fairly high but variable } \mathrm{C} / \mathrm{N} \text { ratio } \\
(15-25) \text {. }\end{array}$ \\
\hline GZ IV-1 & $\begin{array}{c}3,03-2.20 \\
\sim 4,650-3,250\end{array}$ & $\begin{array}{l}\text { Representing the lower part of the fine-detritus gyttja layer. Variable OM con- } \\
\text { centration (usually } 40-75 \% \text { ) and biogenic element contents. Rapid decline in } \mathrm{Ca} \\
\text { content and gradual increase in that of } \mathrm{Zn} \text {. Contents of most lithophile elements } \\
\text { somewhat lower than in GZ III- } 2 \text {. Higher values of mechanical denudation indi- } \\
\text { cators resulting primarily from rapid reduction in Ca content. Periodical increases } \\
\text { of } \mathrm{Fe} / \mathrm{Mn} \text { above } 50 \text { suggesting hypoxia/anoxia. C/N ratio decline to about } 10 \text {. }\end{array}$ \\
\hline GZ IV-2 & $\begin{array}{c}2.20-1.10 \\
\sim 3,250-1,450\end{array}$ & $\begin{array}{l}\text { Representing the upper part of the fine-detritus gyttja layer. Variable OM con- } \\
\text { centrations (usually } 40-60 \%) \text {, peaking }(\sim 90 \%) \text { in uppermost part of the zone and } \\
\text { correlated with variable contents of biogenic elements. Somewhat higher con- } \\
\text { tents of lithophile elements }(\mathrm{K}, \mathrm{Mg}, \mathrm{Fe}) \text { and } \mathrm{Pb} \text {, and lower contents of } \mathrm{Ca} \text { and } \mathrm{Mn} \\
\text { compared to those in GZ IV-1. Variable, although decidedly higher values of me- } \\
\text { chanical denudation indicators and Fe/Mn ratio. Distinct increase in } \mathrm{C} / \mathrm{N} \text { ratio in } \\
\text { uppermost layer, correlated with maximum OM and total carbon contents. }\end{array}$ \\
\hline GZ V & $\begin{array}{l}1.10-0.00 \\
\sim 1,450-0\end{array}$ & $\begin{array}{l}\text { Representing the uppermost layers of lacustrine deposits developed as fine- and } \\
\text { coarse-detritus gyttja. Variable but usually high contents of OM and biogenic ele- } \\
\text { ments. Variable contents of lithophile elements ( } \mathrm{Na}, \mathrm{K}, \mathrm{Mg} \text { and Fe), but some- } \\
\text { what lower than in GZ IV-2. Clearly higher contents of } \mathrm{Ca}, \mathrm{Mn} \text { and trace metals, } \\
\text { particularly } \mathrm{Pb} \text {. Declining values of mechanical denudation indicators; distinct } \\
\text { increase in values of chemical denudation indicators }(\mathrm{Na} / \mathrm{K} \text { and } \mathrm{Ca} / \mathrm{Mg} \text { ). Gradual } \\
\text { increase in Fe/Mn ratio attesting to persistence of oxygen deficiency. } \mathrm{C} / \mathrm{N} \text { ratio } \\
\text { stabilised at about } 10-12 \text {. }\end{array}$ \\
\hline
\end{tabular}



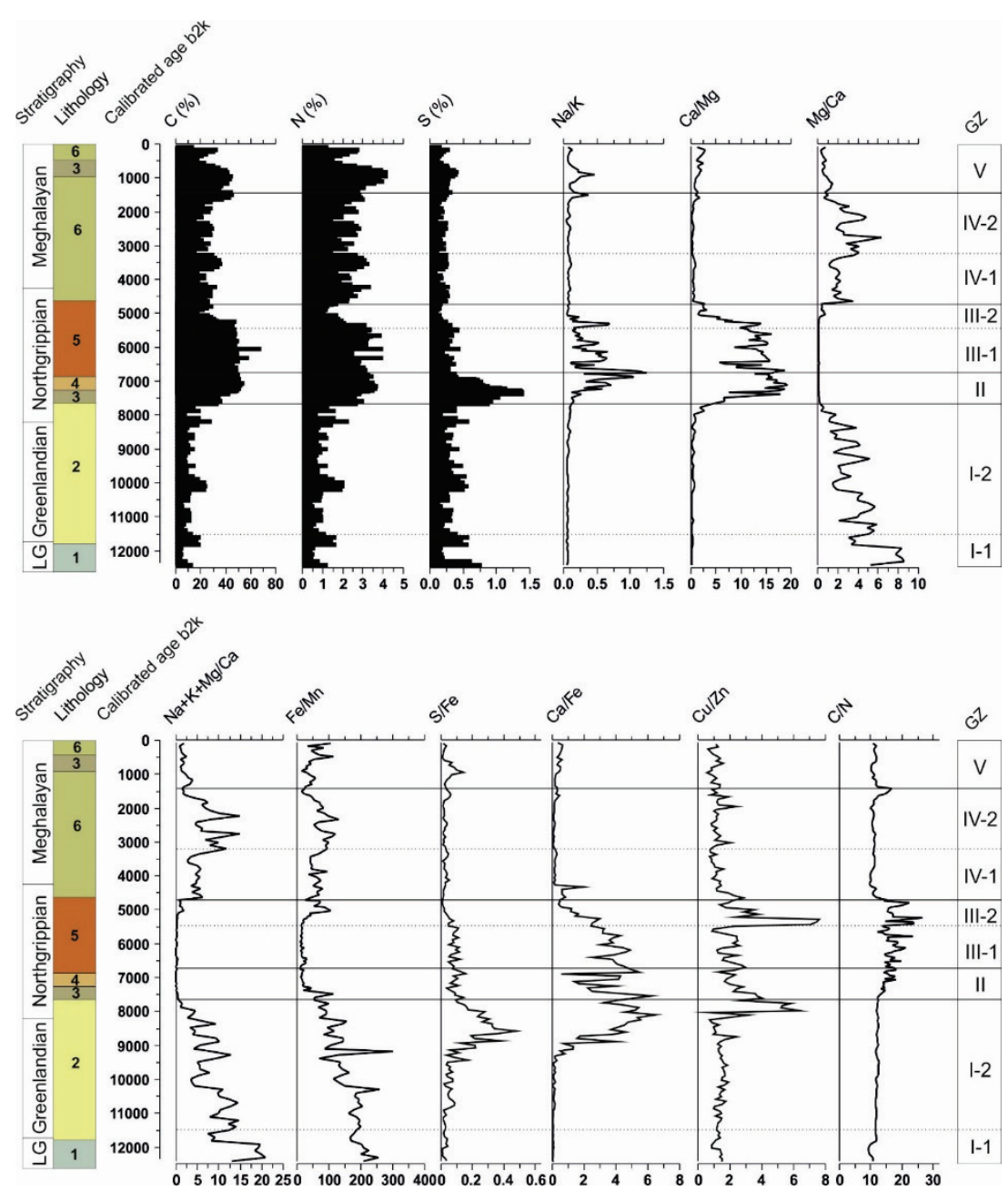

Fig. 6. Core GOS 1. Stratigraphic variability of biophilic elements and selected geochemical indicators for explanation see Fig. 5

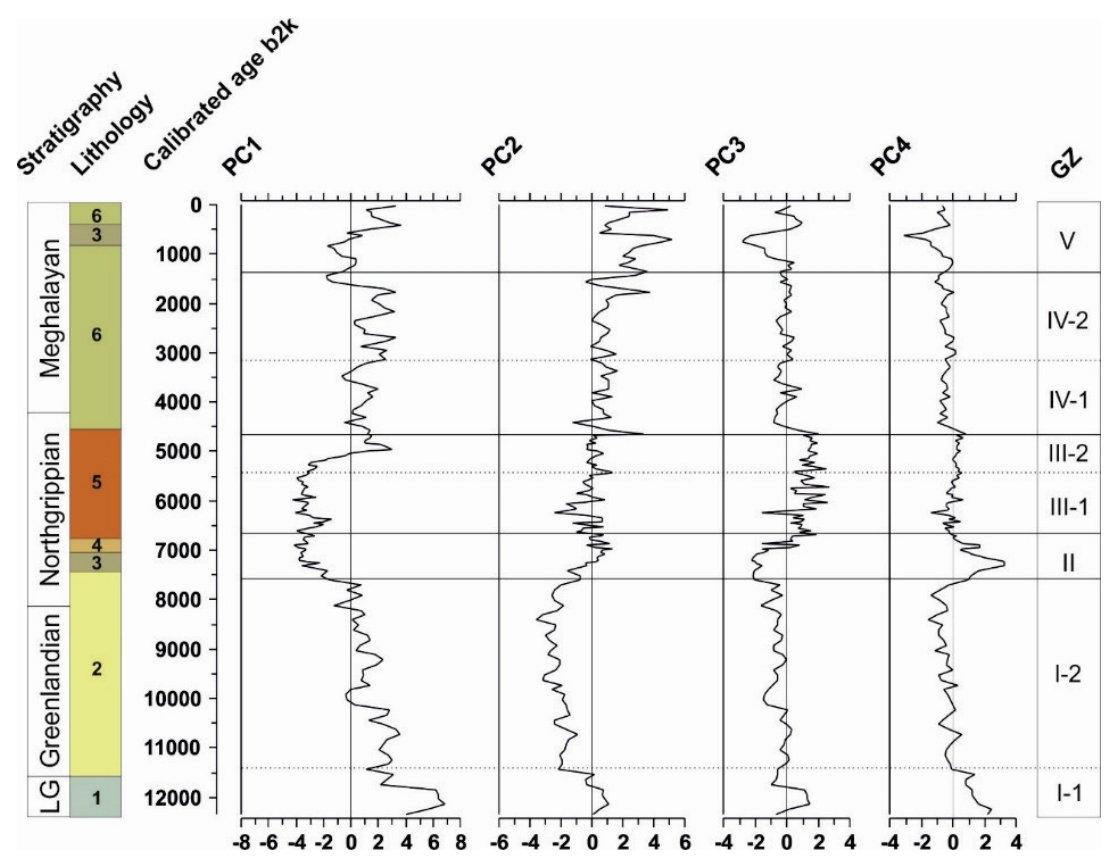

Fig. 7. Core GOS 1. Stratigraphic variability of the four principal components for explanations see Fig. 5 
Table 4

Results of Principal Components Analysis (PCA) for contents of selected major and trace elements in core GOS 1 sediment

\begin{tabular}{|c|c|c|c|c|}
\hline Element & PC1 & PC2 & PC3 & PC4 \\
\hline Organic matter & $\mathbf{- 0 . 8 9 1}$ & 0.365 & 0.081 & 0.022 \\
\hline $\mathrm{Na}$ & $\mathbf{0 . 8 0 5}$ & 0.464 & 0.178 & 0.093 \\
\hline $\mathrm{K}$ & $\mathbf{0 . 9 5 1}$ & 0.080 & 0.118 & 0.148 \\
\hline $\mathrm{Ca}$ & $\mathbf{- 0 . 7 6 0}$ & 0.104 & $\mathbf{0 . 4 2 1}$ & 0.337 \\
\hline $\mathrm{Mg}$ & $\mathbf{0 . 8 9 8}$ & 0.141 & 0.221 & 0.250 \\
\hline $\mathrm{Fe}$ & $\mathbf{0 . 8 9 9}$ & 0.047 & 0.120 & 0.337 \\
\hline $\mathrm{Mn}$ & -0.463 & $\mathbf{0 . 5 6 0}$ & $\mathbf{0 . 5 8 0}$ & 0.108 \\
\hline $\mathrm{Cu}$ & 0.313 & $\mathbf{0 . 8 1 6}$ & -0.064 & 0.092 \\
\hline $\mathrm{Zn}$ & 0.324 & $\mathbf{0 . 7 6 6}$ & $\mathbf{- 0 . 3 9 4}$ & -0.089 \\
\hline $\mathrm{Pb}$ & 0.483 & $\mathbf{0 . 5 2 3}$ & $-0,174$ & -0.320 \\
\hline Total C & $\mathbf{- 0 . 8 8 9}$ & 0.382 & 0.035 & 0.082 \\
\hline Total N & $\mathbf{- 0 . 7 1 7}$ & $\mathbf{0 . 5 4 7}$ & -0.256 & -0.044 \\
\hline Total S & -0.301 & -0.077 & $\mathbf{- 0 . 5 9 3}$ & $\mathbf{0 . 7 3 4}$ \\
\hline $\begin{array}{c}\text { Variance } \\
\text { explained (\%) }\end{array}$ & 50.65 & 20.60 & 9.52 & 7.27 \\
\hline $\begin{array}{c}\text { Cumulative } \\
\text { variance explained (\%) }\end{array}$ & 50.65 & 71.25 & 80.77 & 88.04 \\
\hline
\end{tabular}

The PC2 axis, which explained $20.6 \%$ of the total variance, is positively correlated with contents of trace metals (mainly $\mathrm{Cu}$ and $\mathrm{Zn}$ and, to a lower extent, $\mathrm{Mn}$ and $\mathrm{Pb}$ ) as well as the total nitrogen content. Thus, it may be presumed that PC2 informs on changes associated with human impact, reflecting the supply of additional amounts of metals used in ancient history. Higher nitrogen concentrations may be associated with a growing importance of animal husbandry. Analysis of variability in the first two principal components shows their positive values, appearing from the bottom of GZ III-2 (Fig. 7), i.e., since $\sim 5,450 \mathrm{~b} 2 \mathrm{k}$ (3450 BC), to be associated with variations in the anthropogenic effects on the Gostyń Lake catchment environment. Human impact induced changes in the mechanical denudation intensity, probably coupled with transformations of the vegetation cover, the changes being initially associated with growing animal husbandry and later on with plant cultivation. Such interpretation is completely in agreement with results of palynologi$\mathrm{cal}$ and geochemical analyses of the sediment from Racze Lake on the Pyrzyce Lowland (Bloom 2015). That lake, too, showed a substantial increase - since about $3550 \mathrm{BC}-$ in the mineral matter concentration, accompanied by an increase in contents of the lithophile elements ( $\mathrm{Na}, \mathrm{K}, \mathrm{Mg}, \mathrm{Fe})$. The changes in the geochemical proxies referred to occurred during a period of distinct transformation of the land cover and fire activity in NW Poland and East Germany (Fig. 8D). The role of the latter factor was dealt with by, inter alia, Tobolski (1976) in the context of changes in the woodland structure (e.g., Fagus sylvatica and Pinus sylvestris as important sylvigenic drivers). In addition, the elevated trace element contents and a concomitant increase in the $\mathrm{Mg}$ content recorded in the Suwałki Lakeland water basins are typical of lakes with catchments in morainic areas. The PCA conducted by Bojakowska and Gliwicz (2012) for NE Poland suggested this was a geogenic factor.

The PC 3 axis, which explained $9.5 \%$ of the total variance, was positively correlated with the $\mathrm{Mn}$ and $\mathrm{Ca}$ contents, a negative correlation being seen with those of sulphur and zinc (Table 4). Therefore, PC3 may be taken as informing on changes in redox conditions prevailing during the Gostyń sediment accumulation. Positive values of PC 3 appear in the geochemical zones GZ III-1 and GZ III-2, i.e., when the sedimentary basin experienced subaerial sedentation of moss peat, featuring elevated contents of $\mathrm{Mn}$ and $\mathrm{Ca}$ (Fig. 5). At the same time, the $\mathrm{Fe} / \mathrm{Mn}$ ratio in those layers were the lowest (Fig. 6), indicating a domination of oxidising conditions. Negative values of $\mathrm{PC} 3$ were observed in the geochemical zone GZ II and in the middle part of GZ V (Fig. 7), where the total sulphur contents were elevated (Fig. 6). High sulphur contents are primarily associated with anaerobic decomposition of organic remains, usually mediated by anaerobic bacteria. Some of the hydrogen sulphide pool formed then reacts with trace metal compounds, which induces precipitation of authigenic sulphur minerals, primarily framboid forms of pyrite (Sawłowicz 1993, 

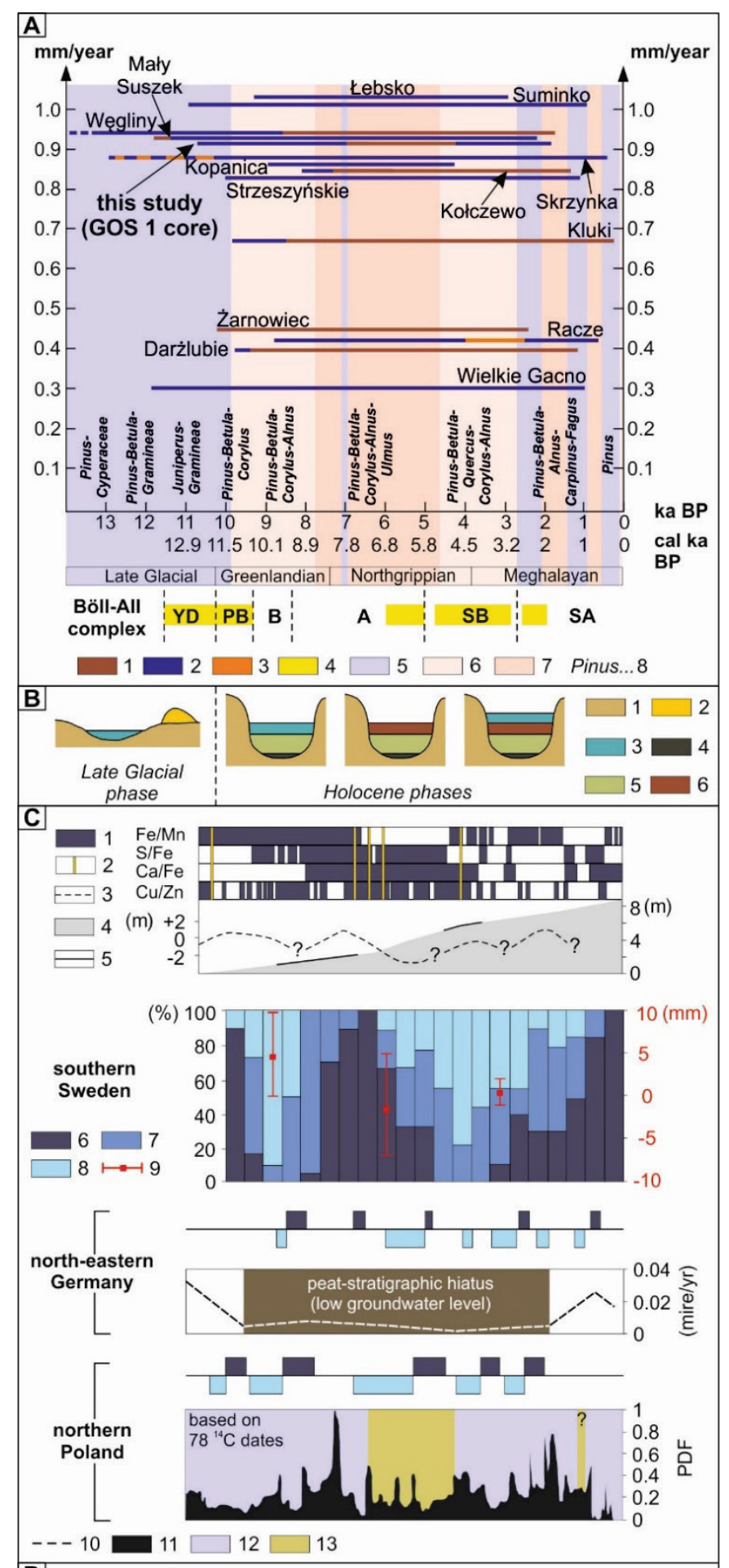

D

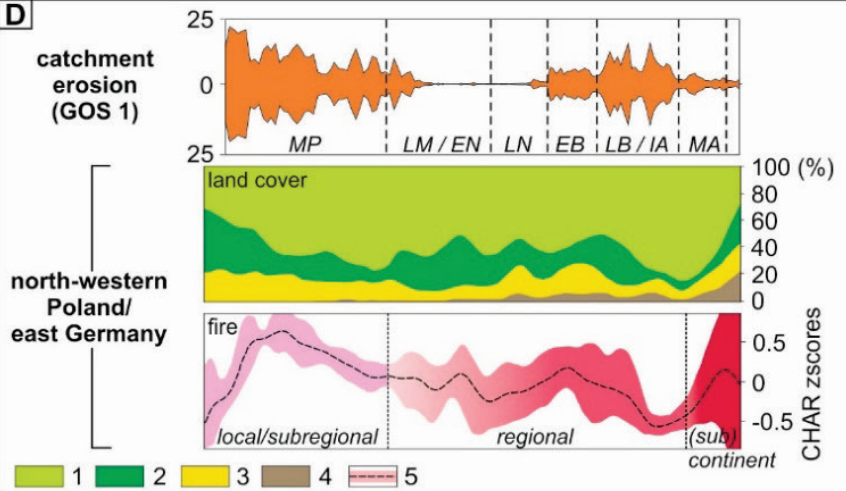

Fig. 8. Palaeo-environmental changes in Gostyń Lake reconstructed from geochemical data (core GOS 1)

A. Average rate of biogenic sediment accumulation ( $\mathrm{mm} / \mathrm{yr})$ in Gostyń Lake against other lakes and peatlands in north-western Poland (based on Latałowa 1982, 1992; Żurek 1986, 1987; Miotk-Szpiganowicz 1992; Apolinarska et al. 2012; Jurochnik, Nalepka 2013; Pędziszewska et al. 2015; Staszak-Piekarska, Rzodkiewicz 2015; Pleskot et al. 2018; Sobkowiak-Tabaka et al., 2020), the time scale of Late Glacial and Holocene after Starkel et al. (2013) and Walker et al. (2018); climate periodisation after Tolksdorf, Kaiser (2012); regional pollen assemblage zones after Miotk-Szpiganowicz (1992), Jurochnik, Nalepka (2013), Okuniewska-Nowaczyk, Sobkowiak-Tabaka (2014), Malkiewicz (2017); periods of aeolian activity resulting from climate change and anthropogenic effects after Kozarski et al. (1969)

1 - peat deposit; 2 - lake sediments (organic, mineral or calcareous gyttja); 3 - mineral sediment; 4 - natural and anthropogenic aeolian activity; 5 - cooling; 6 modern temperature as reference; 7 - warming, 8 -regional pollen assemblage zones

B. Main Late Glacial and Holocene phases of Gostyń Lake evolution

1 - moraine bedrock; 2 - dunes near Barlinek and Gorzów Wielkopolski; 3 - lake water; 4 - silt; 5 - gyttja; 6 - sedge-moss peat

C. Gostyń Lake (core GOS 1) redox conditions against the backdrop of Holocene hydroclimatic conditions as inferred from multiproxy analyses for Central Europe (after Ralska-Jasiewiczowa 1989; Harisson et al. 1993; Couwenberg et al. 2001; Janke 2004; Michczyńska et al. 2013)

1 - redox ratios above the median for core GOS $1 ; 2-$ boundary of biogenic deposits in core GOS $1 ; 3$ - water level changes in Lake Gościąż; 4 - total biogenic sediment thickness in core GOS $1 ; 5$ - periods of negative Fe-mineral matter correlation in core GOS $1 ; 6$ - high level; 7 -intermediate level; 8 - low level; 9 -changes in annual precipitation and evapotranspiration anomaly for $3 \mathrm{ka}, 6 \mathrm{ka}$ and $9 \mathrm{ka} \mathrm{BP} ; 10$ - bog formation; 11 probability density function (PDF) for peat samples above limnic sediments; 12 - limnic deposit ( $\mathrm{C} / \mathrm{N}$ ratio about 10$) ; 13$ - telmatic deposit ( $\mathrm{C} / \mathrm{N}$ ratio above 15$)$

D. Changes in catchment erosion as inferred from $\mathrm{Na}+\mathrm{K}+\mathrm{Mg} / \mathrm{Ca}$ ratio in core GOS 1 against the backdrop of sub-regional land cover and Holocene fire activity after Dietze et al. (2018)

1 - arboreal; 2 - Scots pine; 3 -open land; 4 - human activity; archaeological periods: MP - Mesolithic (LM, late Mesolithic), EN/LN - early/late Neolithic, BA Bronze Age, IA - Iron Age; MA, Medieval 
2000) as well as zinc and copper sulphides (Cieśla, Marciniak 1982; Bojakowska, Sokołowska 1997; Migaszewski, Gałuszka 2007). As shown by Enters et al. (2010) for sediments of Sacrower See in NE Germany, incorporation of $\mathrm{Mn}$ into authigenic carbonates can be an important factor controlling the sediment chemical composition and, in conjunction with the removal of dissolved $\mathrm{Fe}^{2+}$, leads to a reduction in the $\mathrm{Fe} / \mathrm{Mn}$ ratio. In addition, the associated changes in geochemical indicators such as the $\mathrm{Na} / \mathrm{K}$ and $\mathrm{Mg} / \mathrm{Ca}$ ratios, interpreted as indicating the dominant type of denudation, may result from natural climate changes as well as from the presence of advantageous physical and chemical components in the parent rock making up the lake's catchment, ultimately leading to leaching and acidification of the soil cover.

The PC4 axis, which explained $7.3 \%$ of the total variance, was most strongly positively correlated with sulphur (Table 4), which may suggest the presence of strongly reducing conditions. The positive PC4 values occurred in the geochemical zones GZ I-1 and GZ II (Fig. 7). According to Rydelek (2005), the contribution of sulphur to biogenic accumulation in the basin is governed mainly by the location of the water table, which controls the accumulation conditions and organic matter decomposition. Also key for the reconstruction of redox conditions using stratigraphic variability in the $\mathrm{S}$ concentration is the detrital input resulting from substitution of the catchment-derived $\mathrm{Fe}$ and $\mathrm{Mn}$ in calcite (Eusterhues et al. 2005). As a result, pyrite precipitation in Gostyń Lake could have proceeded in two ways: syngenetically, i.e., during prolonged periods of anoxia, or diagenetically, under fairly aerobic conditions.

\section{Gostyń Lake evolution phases against the background of major natural processes changes and human impact}

The major stages in the Gostyń Lake evolution, reconstructed from geochemical data, are illustrated in Fig. 8. The uppermost panel (Fig. 8A) shows average biogenic sediment accumulation rates at selected sites (lakes and peatlands) in NW Poland. In many cases (e.g., Kołczewo, Kluki, Węgliny), Holocene peatlands developed as a result of aquatic areas becoming terrestrialised. Holocene environmental changes at other sites were reconstructed from lacustrine sediments (e.g., Wielkie Gacno, Suminko), and less frequently from such sediments intercalated by mineral deposits (e.g., Lake Racze on Wolin Island).

In the first phase of Gostyń Lake's evolution, during the Late Glacial and the onset of the Holocene, the water level began to rise (Fig. 8B). The lacustrine sediment accumulation rate, estimated at $0.41 \mathrm{~mm} / \mathrm{yr}$ (Fig. 4) occurred during distinctly elevated values of redox indicators (Fig. 8C). The sediment chemical composition data evidence a close relationship between the iron concentration and the concentration of mineral matter or the catchment erosion index along most of the GOS 1 profile. As a result, the stratigraphic variability of the $\mathrm{Fe} / \mathrm{Mn}$ ratio could have resulted, in part, from the intensity of denudation processes in the catchment, and to a lesser extent from the redox conditions, as pointed out earlier by, inter alia, Tribovillard et al. (2006), Borówka (2007) and Żarczyński et al. (2019). In the Gostyń sediments, two Holocene sections (the entire Greenlandian and the end of the Northgrippian) constitute exceptions in this regard and correspond to a generally high water level in Gościąż Lake (Fig. 8C). The high values of the catchment erosion index recorded at the initial phase of the Gostyń Lake evolution are a regional characteristic that has been reported for numerous sites in the Polish Lowland, for example from the lakes Woryty (Pawlikowski et al. 1982), Gościąż (Łącka et al. 1998), Ostrowite (Kowalewski et al. 2006) and Skrzynka (Apolinarska et al. 2012).

Analysis of geochemical data of the Gostyn sediments being deposited during the middle (Northgrippian) and final (Meghalayan) stages of the Holocene, i.e., since about $8,000 \mathrm{~b} 2 \mathrm{k}$, allows it to be contended that the onset of the Northgrippian was accompanied by a distinct change in the sediment lithology, testifying to a gradual shallowing of the lake and it becoming a peat bog. The termination of the lacustrine phase coincided, however, with an increase in the sediment accumulation rate to $1.68 \mathrm{~mm} / \mathrm{yr}$ at the initial stage of the peat bog formation (Fig. 4). A sediment accumulation rate of a similar order of magnitude was documented by Kowalewski (2014) for heavily hydrated peat in the central part of the fossil Bor Bagienny Lake basin in the Tuchola Forest. The change was primarily climate-driven. At that time, after the 8,200-BP event, the air temperature was gradually increasing to peak about $7,000 \mathrm{~b} 2 \mathrm{k}$ (Heikkila, Seppa 2010; Edvardsson et al. 2016). At the same time, Western Pomerania was experiencing maturation of forest ecosystems, the photophilous trees being replaced by much more environmentally demanding deciduous ones (Madeja 2012; Bloom 2015), which must have resulted 
in increasing evapotranspiration and ultimately in the groundwater level being lowered. The evapotranspiration-regime-controlled Gostyń Lake, situated on a morainic upland and filling a drainless depression, was no longer fed by subsurface water, which led to its gradual drying out; eventually, about 7,650 b2k, it changed into a peat bog. The most legible record of the biogenic accumulation basin changing from aquatic to terrestrial is found in the $\mathrm{C} / \mathrm{N}$ ratio. During a period from about 7,300 to $5,100 \mathrm{~b} 2 \mathrm{k}$, the $\mathrm{C} / \mathrm{N}$ ratio is observed to have increased from 14 to 26 . Subsequently, within 5,100-4,600 b2k, the ratio dropped to 10-12. According to Meyers (1994), these are values typical of terrestrial plants, the autochthonous lacustrine organic matter typically showing relatively low $\mathrm{C} / \mathrm{N}$ ratios (usually below 10 ).

The period discussed was characterised by a distinct increase in the number of lakes with a low water level in southern Sweden (Harisson et al. 1993), a low groundwater level in north-eastern Germany (Couwenberg et al. 2001; Janke 2004), and the longest-lasting Holocene low water level phase in lakes of northern Poland (Ralska-Jasiewiczowa 1989), with a concurrent increase in the number of sites showing a change in biogenic sedimentation from limnic to peatland (Michczyńska et al. 2013) (Fig. 8C). The profile reflected in core GOS 1 showed it initially to be a low, sedge-type, peat bog, grading - as of about $6,850 \mathrm{~b} 2 \mathrm{k}$ - into a transitional, moss-type bog (Table 3 ) fed mainly by precipitation and periodically by the supply of surface or subsurface hydrocarbon-rich water. Such conditions were amenable to calcium carbonate precipitation in warm and $\mathrm{CO}_{2}$-depleted peat bog water. An average $\mathrm{Ca}$ content in moss peat (GZ III-1 and GZ III-2) of about $8-13 \mathrm{mg} / \mathrm{g}$ d.w. (Fig. 5) shows that without palaeobotanical data it is difficult to conclude whether the peat bog was ombrogenic or transient. Ombrogenic peat bogs usually show a much lower average Ca content, up to as little as $2 \mathrm{mg} / \mathrm{g}$ (Borówka 1992; Słowiński et al. 2016). However, the small sedimentary basin of Gostyn Lake, situated at the time within a multi-species deciduous or mixed woodland, suggests that some of the calcium present may have been derived from decomposition of leaves, usually Ca-rich - particularly in the Quercetum mixtum associations - blown into the peat bog by the wind (Rodin, Bazylević 1965; Fortescue 1980).

Towards the termination of the moss peat sedentation (GZ III-2), i.e., since about 5,450 b2k (3450 BC), the deposit's geochemical properties underwent a distinct change expressed primarily as increasing contents of lithophile $(\mathrm{Na}, \mathrm{K}, \mathrm{Mg}, \mathrm{Fe})$ and trace elements $(\mathrm{Cu}, \mathrm{Zn}, \mathrm{Pb})$, with a concurrent decline in the concentration of organic matter and contents of biogenic elements (Figs 5, 6). The sediment lithology changed as well, the change evidencing the peat bog inundation and the sedimentation basin turning limnic. The higher contents of lithophile elements attest to mobilisation of mechanical denudation processes, as confirmed also by the erosion indicator $(\mathrm{Na}+\mathrm{K}+\mathrm{Mg} / \mathrm{Ca})$ and the $\mathrm{Mg} / \mathrm{Ca}$ ratio (Fig. 6). These data allow it to be presumed that the Gostyń Lake catchment experienced a substantial change in the type of vegetation, enhancing mechanical denudation. Most likely, the upland area in the immediate vicinity of the lake became partly deforested, which led to reduced evapotranspiration, a renewal of subsurface water resources and an increased water level in the lake. The cause of those environmental changes should most likely be sought in intensified human impact, as documented - on the regional scale - by Dietze et al. (2018). The archaeological and palaeo-ecological data collected from Racze Lake (Bloom 2015), not particularly far from Gostyń, showed the environmental changes discussed to have coincided with the expanding of the FBC communities. However, results of surveys carried out within the framework of the AZP showed the closest settlements to be present and fairly abundant in Dziedzice village only, about $5 \mathrm{~km}$ to the NW of Gostyń, a single settlement being identified near Osina village, $2.5 \mathrm{~km}$ ENE of the lake (Fig. 2). Nevertheless, the timing of a distinct increase in the mechanical denudation in both Racze Lake (Bloom 2015) and Gostyń Lake was similar, i.e., about $5,500 \mathrm{~b} 2 \mathrm{k}$. An increased supply of allochthonous geochemical components at that time was observed also by Tobolski (1987) in the Kluki peat bog deposits and Sobkowiak-Tabaka et al. (2020) in the Kopanica peat bog.

The geochemical data show a more distinct intensification of mechanical denudation in the Gostyń Lake catchment to have begun at about 4,650 b2k (2650 BC), i.e., still during the FBC prevalence in Pomerania (Jankowska 1980, 1990, 2005), and to continue until 3,250 b2k (1250 BC), i.e., until the middle Bronze Age. The biogenic deposits from that period showed a three-fold increase in the contents of $\mathrm{Cu}, \mathrm{Zn}$ and $\mathrm{Pb}$. An accelerated circulation of elements in numerous lakes was explained by developing settlements and catchment deforestation coupled with the use of copper products and mineral dyes (Cieśla, Stupnicka 1980; Hildebrandt-Radke et al. 2011; Owsianny et al. 2011; Forysiak et al. 2012). However, 
Woszczyk and Spychalski (2013) demonstrated that the metals mentioned occur in the sediments in various forms (exchangeable, acid-extractable, reducible, oxidisable, and residual) which, in addition, could have been altered quantitatively during the Holocene. The authors mentioned are of the opinion that the three distinct shifts in the total content of trace elements and their total content in chemical fractions of the Lake Sarbsko sediment were caused by, inter alia, changes in sediment lithology and human impact.

The next, rapid increase in mechanical denudation intensity is typical of the geochemical zone GZ IV-2 spanning the period of 3,250-1,450 b2k (1250 BC-550 AD). This is the time when the Lusatian Culture developed, expanded and dwindled, followed by the occupation of the Pre-Roman Period and the Roman Period as well as the Migration Period peoples. Although no archaeological site that could be dated to that period was identified in the direct Gostyń Lake catchment, there are many such sites in the environs (Fig. 2), although most of them lack a detailed chronology and have not been excavated. Much better archaeological evidence pertains to the Bronze Age settlements in the neighbouring, western part of the Myślibórz Lakeland (Wesołowski 1996; Kot 2013). The municipalities of Myślibórz and Nowogródek Pomorski alone feature, based on the AZP data and results of excavations, 14 Lusatian Culture settlements dated to the Late Bronze and the Early Iron Ages (Kot 2013). As shown by Kot (2013), numerous (more than 200) Lusatian Culture sites, dated both to the Bronze Age and the Early Iron Age (the Hallstatt Period) are located primarily on slopes and margins of small valleys, while settlements outside valleys, particularly on upland plateaus, are much rarer. Such settlements were usually located on exposed areas in the vicinity of lakes, streams and current wetlands, but very seldom on the bottom of a valley (Kot 2013). It follows then that the recently glaciated area of the Myślibórz Lakeland was fairly attractive to the Lusatian Culture settlers, and the low number of well-documented archaeological sites in its eastern part (the environs of Barlinek) may result from the dearth of studies in the area. Results of geochemical research on Gostyń Lake indicate a substantial effect of Bronze Age and Iron Age settlers on the catchment ecosystem and are firmly embedded in the picture of the human signature and effects of man's economic activities in western Poland (Fig. 8D).

The period from the Early Middle Ages until present is reflected in the geochemical zone GZ V
(1450-0 b2k; 550-2000 AD). The two first components providing information on growing human impact after a periodic decline during the Migration Period demonstrate its increasing importance. This is evident primarily in increased contents of trace metals $(\mathrm{Cu}, \mathrm{Zn}$ and $\mathrm{Pb})$, and periodically particularly since the $14^{\text {th }}$ century $A D$ - also of lithophile elements $(\mathrm{K}, \mathrm{Mg}$ and $\mathrm{Fe})$ as well as $\mathrm{Ca}$. The elevated content of calcium, as well as the $\mathrm{Ca} / \mathrm{Mg}$ and $\mathrm{Na} / \mathrm{K}$ ratios, may be indicative of a periodic increase in the importance of soil leaching in the Gostyń Lake catchment. On the other hand, the passive supply of calcium together with the lithophile elements that result from intensive soil erosion associated with the prevailing agricultural practices cannot be ruled out. This may be suggested by the escarpments resulting from ploughing that occur around the western, southern and eastern shores of the lake. The archaeological evidence shows early-medieval settlements to be present in the direct vicinity of the north-eastern shores (Fig. 3).

According to the site catchment analysis ( $c f$ Kobyliński 1986) assumptions, the zone of intensively used areas near Gostyń Lake could extend to a maximum of $1 \mathrm{~km}$ from the settlements. In this case, the mires related to small lake basins (near Barlinek) and the river (near Dziedzice) favoured the development of hydrogenic soils and could potentially provide higher yields in garden cultivation. The small distances between prehistoric settlements found in other regions of the Polish Lowland are associated with areas of high geodiversity (Pelisiak 1991; Kittel 2012).

An important role in shaping the intensity of Late Glacial and Holocene evolution of the slopes of the Gostyn Lake was played by the geological surface structure, relative height not exceeding 10 $\mathrm{m}$ and average slopes not exceeding $1^{\circ}$. However, the spatial differentiation of the surface runoff on till need not have translated into higher erosion intensity, which results from their greater erosion resistance. This is evidenced by the stratigraphic variability of the erosion rate calculated for the GOS 1 core. This problem requires further research, especially in the context of the morphodynamics of the young-glacial relief dependent not only on the lithology of the sediments that build the catchment area but also on the transformations of the soil cover (Stach 2003). These changes are highly related to human activity, which is reflected in the physicochemical properties of deposits filling biogenic accumulation basins (Borówka 1992; Karasiewicz et al. 2014b). An exceptional role in the 
lithological and geochemical record of palaeo-environmental changes can be played by evaporation basins, the functioning of which is related to surface retention possibilities, climatic conditions and the drainage deficit of the river network.

\section{Conclusions}

The results of the geochemical analyses for biogenic deposits in Gostyń Lake point to highly dynamic environmental changes in the area from the end of the Late Glacial until today. Principal Components Analysis (PCA) identified four major geochemical variable groupings. The changes concerned the water level, as recorded by the Fe/Mn, $\mathrm{Ca} / \mathrm{Fe}, \mathrm{S} / \mathrm{Fe}$ and $\mathrm{Cu} / \mathrm{Zn}$ ratios; organic matter accumulation milieu (limnic and telmatic); and catchment erosion intensity, reflected by the $\mathrm{Na}+\mathrm{K}+\mathrm{Mg} / \mathrm{Ca}$ ratio. In the first two cases, the processes and sedimentation conditions recorded resulted from natural Holocene hydroclimatic conditions and are in agreement with evidence reported from other Central European lakes. It must be emphasised, however, that geochemical indicators of changes in redox conditions in the near-bottom water layers of the lakes should be interpreted with due consideration of local geochemical background as well as the geological and lithological set-up of the catchment. Analyses of lithophile element contents evidence highly dynamic denudation processes in the Gostyń Lake catchment during the Late Glacial, at the onset of the Holocene, and since the Northgrippian/Meghalayan. The causes should be sought in changes in the vegetation cover and land-use practices in Western Pomerania, which have been documented palynologically at numerous sites elsewhere in the western part of Poland and the eastern part of Germany. The chemical data collected reflect a close association between climate change and terrain relief types preferred by early settlers.

\section{References}

Apolinarska K., Woszczyk M., Obremska M. 2012. Late Weichselian and Holocene palaeoenvironmental changes in northern Poland based on the Lake Skrzynka record. Boreas 41: 292-307.

Bloom K. 2015. Wpływ czynników naturalnych i gospodarki pradziejowej na sukcesję roślinności w rejonie Jeziora Raczego na Ziemi Pyrzyckiej w holocenie. Studium paleoekologiczne. PhD Thesis, University of Gdańsk, Gdańsk.

Błaszkiewicz M. 2007. Geneza i ewolucja mis jeziornych na młodoglacjalnym obszarze Polski - wybrane problemy. Studia Limnologica et Telmatologica 1,1: 5-16.

Bojakowska I., Gliwicz T. 2012. Pierwiastki śladowe w osadach jezior Suwalszczyzny. Prace $i$ Studia Geograficzne Uniwersytetu Warszawskiego 50: 11-18.

Bojakowska I., Sokołowska G. 1997. Akumulacja pierwiastków śladowych w osadach jeziornych w zależności od strefy ich sedymentacji. Przegląd Geologiczny 45,5: 505-508.

Borówka R.K. 1990. Denudation process intensity in Vistulian till plains in relations to prehistoric settlement and human activity, Leszna region, Middle Great Poland. Quaestiones Geographicae 13/14: 5-18.

Borówka R.K. 1992. Przebieg i rozmiary denudacji w obrębie śródwysoczyznowych basenów sedymentacyjnych podczas późnego vistulianu i holocenu. Uniwersytet im. Adama Mickiewicza w Poznaniu, Seria Geografia 54, Wydawnictwo Naukowe UAM, Poznań.

Borówka R.K. 1994. Denudation processes during the Holocene conditioned by natural and man-made factors. Roczniki Akademii Rolniczej w Poznaniu 266: 27-37.

Borówka R.K. 2007. Geochemiczne badania osadów jeziornych strefy umiarkowanej. Studia Limnologica et Telmatologica 1,1: 33-42.

Bronk Ramsey C., Lee S. 2013. Recent and planned developments of the Program OxCal. Radiocarbon 55(2-3): 720-730.

Bronk Ramsey C., Dee M., Lee S., Nakagawa T., Staff R. 2010. Developments in the calibration and modelling of radiocarbon dates. Radiocarbon 52,3: 953-961.

Cieśla A., Marciniak B. 1982. Rozwój późnoglacjalnych zbiorników jeziornych z Niechorza (Pomorze Zachodnie) w świetle analizy diatomologicznej i geochemicznej. Kwartalnik Geologiczny 26,1: 191-215.

Cieśla A., Stupnicka E. 1980. Wpływ osadnictwa na skład chemiczny osadów jeziornych. Archeologia Polski 24,1: 7-19.

Chmielewski W. 1952. Zagadnienie grobów kujawskich w świetle ostatnich badań. Wydawnictwo Muzeum Archeologicznego, Łódź.

Choiński A., Jańczak J., Ptak M. 2020. Wahania poziomów wody jezior w Polsce w latach 19562015. Przeglad Geograficzny 92,1: 41-54.

Couwenberg J., de Klerk P., Endtmann E., Joosten H., Michaelis D. 2001. Hydrogenetische Moortypen in der Zeit - eine Zusammenschau. In: M. Succow, H. Joosten (eds) Landschaftsokologische Moorkunde. E. Schweizerbart'sche Verlagsbuchhandlung, Stuttgart: 399-403.

Czerniak L., Matuszewska A., Pospieszny Ł., Ryndziewicz R. 2019. Badania neolitycznego rondela w Nowym Objezierzu w 2018 roku. Zachodniopomorskie Wiadomości Konserwatorskie VIII: 145-155. 
Dean W. 1993. Physical properties, mineralogy, and geochemistry of Holocene varved sediments from Elk Lake, Minnesota. Geological Society of America, Special Papers 276: 135-157.

Dietze E., Słowiński M., Zawiska I., Veh G., Brauer A. 2016. Multiple drivers of Holocene lake level changes at a lowland lake in norteastern Germany. Boreas 45,4: 828-845.

Dietze E., Theuerkauf M., Bloom K., Brauer A., Dorlfer W., Feeser I., Feurdean A., Gedminiene L., Giesecke T., Jahns S., Karpińska-Kołaczek M., Kołaczek P., Lamentowicz M., Latałowa M., Marcisz K., Obremska M., Pędziszewska A., Poska A., Rehfeld K., Stacikaite M., Stivrins N., Święta-Musznicka J., Szal M., Vassiljew J., Veski S., Wacnik A., Weisbrodt D., Wiethold J., Vanniere B., Słowiński M. 2018. Holocene fire activity during low-natural flammability periods reveals scale-dependent cultural human-fire relationships in Europe. Quaternary Science Reviews 201: 44-56.

Drwal J. 1973. Zagadnienie bezodpływowości na obszarach młodoglacjalnych. Zeszyty Naukowe Wydziału Biologii i Nauk o Ziemi Uniwersytetu Gdańskiego, Geografia 3: 7-26.

Drwal J. 1974. Próba określenia typów obszarów bezodpływowych powierzchniowo w warunkach środowiska geograficznego Pojezierza Kaszubskiego. Zeszyty Naukowe Wydziału Biologii $i$ Nauk o Ziemi Uniwersytetu Gdańskiego, Geografia 4: 27-51.

Edvardsson J., Stoffel M., Corona C., Bragazza L., Leuschner H.H., Charman D.J., Helama S. 2016. Subfossil peatland trees as proxies for Holocene palaeohydrology and palaeoclimate. Earth-Science Reviews 163: 118-140.

Enters D., Kirilova E., Lotter A.F., Lucke A., Parplies J., Jahns S., Kuhn G., Zolitschka B. 2010. Climate change and human impact at Sacrower See (NE Germany) during the past 13,000 years: a geochemical record. Journal of Paleolimnology 43: 719-737.

Eusterhues K., Heinrichs H., Schneider J. 2005. Geochemical response on redox fluctuations in Holocene lake sediments, Lake Steisslingen, Southern Germany. Chemical Geology 222: 1-22.

Fortescue J.A.C. 1980. Environmental geochemistry. A holistic approach. Springer-Verlag, New York.

Forysiak J., Borówka R.K., Kloss M., Obremska M., Okupny D., Żurek S. 2012. Geologiczna i geomorfologiczna charakterystyka torfowiska Rąbień oraz wstępne wyniki badań osadów biogenicznych. Acta Geographica Lodziensia 100: 6576.

Galiński T. 1992. Mezolit Pomorza. Muzeum Narodowe w Szczecinie, Szczecin.

Galiński T. 2015. Tanowo. Obozowiska łowców epoki paleolitu i mezolitu na Pomorzu. Instytut Archeologii i Etnologii PAN, Warszawa.
Godłowski K. 1984. Przemiany osadnicze i kulturowe w południowej i środkowej Polsce w młodszym okresie przedrzymskim i okresie rzymskim. Przegląd Archeologiczny 32: 105-155.

Hammer Ø., Harper D.A.T., Rayan P.D. 2001. PAST: Paleontological Statistics software package for education and data analysis. Palaeontologia Electronica 4(1): 1-9.

Harrison S.P., Prentice I.C., Guiot J. 1993. Climatic controls on Holocene lake-level changes in $\mathrm{Eu}-$ rope. Climate Dynamics 8: 189-200.

Heikkila M., Seppa H. 2010. Holocene climate dynamics in Latvia, eastern Baltic region: a pollenbased summer temperature reconstruction and regional comparison. Boreas 39(4): 705-719.

Heiri O., Lotter A., Lemcke G. 2001. Loss on ignition as a method for estimating organic and carbonate content sediments: reproducibility and comparability of results. Journal of Paleolimnology 25: 101-110.

Hildebrandt-Radke I., Spychalski W., Lutyńska M. 2011. Regionalna wymowa procesów antropogenizacji regionu środkowej Obry na podstawie badań osadów jeziora Wonieść. Landform Analysis 16: 92-97.

Hulisz P., Karasiewicz M.T., Dąbrowski M., Michalski M. 2012. Zmiany fizykochemicznych i chemicznych właściwości osadów w odniesieniu do etapów rozwoju zagłębienia w rezerwacie Retno. In: M.T. Karasiewicz, P. Hulisz, M. Świtoniak (eds) Postglacjalna historia zagłębienia bezodptywowego $w$ rezerwacie Retno (Pojezierze Brodnickie). Wydawnictwo Naukowe UMK, Toruń: 131-143.

Janke W. 2004. Holozan im Binnenland. In: G. Katzung (ed.) Geologie von Mecklenburg-Vorpommern. E. Schweizerbart'sche Verlagsbuchhandlung, Stuttgart: 265-284.

Jankowska D. 1980. Kultura pucharów lejkowatych na Pomorzu Środkowym. Grupa łupawska. Wydawnictwo Naukowe UAM, Seria Archeologiczna, nr 17, Poznań

Jankowska D. 1990. Społeczności strefy południowozachodniobałtyckiej w dobie neolityzacji. Wydawnictwo Naukowe UAM, Seria Archeologiczna, nr 33, Poznań

Jankowska D. 2005. O pochodzeniu pomorskich grobowców bezkomorowych kultury pucharów lejkowatych. Folia Praehistorica Posnaniensia 13-14: 133-145.

Jasnowski M. 1962. Budowa i roślinność torfowisk Pomorza Szczecińskiego. Szczecińskie Towarzystwo Naukowe, Szczecin.

Juggins S. 2007. C2. Software for ecological and palaeoecological data analysis and visualisation. User guide Version 1.5 https://www.staff.ncl.ac.uk/ stephen.juggins/software/code/C2.pdf

Jurochnik A., Nalepka D. 2013. Late Glacial and Holocene plant cover in Węgliny, Lubsza Plain, 
south-west Poland, based on pollen analysis. Acta Palaeobotanica 53(2): 191-233.

Kaczmarek M. 2019. Pomorze w epoce brązu - kilka refleksji o stanie i potrzebach badań. Pomerania Antigua 27: 7-22.

Karasiewicz T.M. 2019. The kettle-hole mire as archives of postglacial changes in biogenic sedimentation (Tuchola Forest, north-Central Poland). Catena 176: 26-44.

Karasiewicz T.M., Hulisz P., Noryśkiewicz A.M., Krześlak I., Świtoniak M. 2014a. The record of hydroclimatic changes in the sediments of a kettle-hole in a young glacial landscape (north-central Poland). Quaternary International 328-329: 264-276.

Karasiewicz T.M., Hulisz P., Świtoniak M. 2014b. Effect of denudation processes on properties of sediments filling the intra-glacial curvilineations troughs in Zbójno vicinity (Dobrzyń Lakeland). Landform Analysis 25: 29-42.

Karasiewicz T.M., Hulisz P., Noryśkiewicz A.M., Stachowicz-Rybka R., Michalski A., Dąbrowski M., Gamrat W.W. 2017. The impact of postglacial palaeoenvironmental changes on the properties of sediments in the kettle-hole at Jurki (NE Poland). Geological Quarterly 61(2): 319-333.

Kittel P. 2012. Wpływ georóżnorodności zlewni Neru (Polska środkowa) na lokalizację osadnictwa pradziejowego. Landform Analysis 19: 49-66.

Kobyliński Z. 1986. Koncenpcja "terytorium eksploatowanego przez osadę" w archeologii brytyjskiej i jej implikacje badawcze. Archeologia Polski XXXI,1: 7-30.

Koinig K.A., Shotyk W., Lotter A.F., Ohlendorf C., Sturm M. 2003. 9000 years of geochemical evolution of lithogenic major and trace elements in the sediment of an alpine lake - the role of climate, vegetation, and land-use history. Journal of Paleolimnology 30: 307-320.

Kołodziej J. 2008. Kształtowanie się klimatycznego bilansu wodnego na terenie Polski w latach 1981-2000. Infrastruktura i Ekologia Terenów Wiejskich 5: 85-97.

Kot K. 2013. Osadnictwo kultury łużyckiej w późnej epoce brązu i wczesnej epoce żelaza we wschodniej części Pojezierza Myśliborskiego. Instytut Archeologii Uniwersytetu Lódzkiego, Wydawnictwo Nauka i Innowacje, Poznań.

Kowalewski G. 2014. Alogeniczne i autogeniczne składowe zarastania jezior: hipoteza wahań poziomu wody. Studia Limnologica et Telmatologica, Monographie I: 1-192.

Kowalewski G., Woszczyk M., Milecka K., Bubak I. 2006. Osady denne jeziora Ostrowite. In: G. Kowalewski, K. Milecka (eds) Jeziora i torfowiska Parku Narodowego Bory Tucholskie. Park Narodowy Bory Tucholskie, Charzykowy: $87-100$.

Kowalski K., Kozłowska-Skoczka D. 2009/2010. Przyczynek do badań nad początkami epoki brązu w strefie dolnej Odry. Barnisław stanowisko 32, gm. Kołbaskowo. Materiaty Zachodniopomorskie, Archeologia VI/VII,1: 43-85.

Kozarski S., Nowaczyk B., Rotnicki K., Tobolski K. 1969. The eolian phenomena in west-central Poland with special reference to the chronology of phases of eolian activity. Geographia Polonica 17: 231-248.

Koźmiński C., Michalska B., Czarnecka M. 2012. Klimat województwa zachodnio-pomorskiego. Zachodniopomorski Uniwersytet Technologiczny w Szczecinie, Uniwersytet Szczeciński, Szczecin.

Krupiński K.M. 1991. Flora of Late Glacial and Holocene from Chojna: NW Poland. In: A. Kostrzewski (ed.) Geneza, litologia i stratygrafia utworów czwartorzędowych. Geografia, Wyd. Nauk. UAM, Poznań: 497-510.

Kulczycka-Leciejewiczowa A. 1996. Badania nad osadnictwem neolitycznym we wschodniej części środkowego i dolnego nadodrza. In: L. Leciejewicz, E. Gringmuth-Dallmer (eds) Człowiek $i$ środowisko w środkowym i dolnym nadodrzu. Instytut Archeologii i Etnologii PAN, Wrocław: 41-59.

Lamentowicz M., Gałka M., Lamentowicz Ł., Obremska M., Kühl N., Lücke A., Jassey V.E.J. 2015. Reconstructing climate change and ombrotrophic bog development during the last 4000 years in northern Poland using biotic proxies, stable isotopes and trait-based approach. Palaeogeography, Palaeoclimatology, Palaeoecology 418: 261-277.

Lamentowicz M., Kołaczek P., Mauquou D., Kittel P., Łokas E., Słowiński A., Jassey V.E.J., Niedziółka K., Kajukało-Drygalska K., Marcisz K. 2019. Always on the tipping point - A search for signals of past societes and related peatland ecosystems critical transitions during the last 6500 years in N Poland. Quaternary Sciences Reviews 225: 105954

Latałowa M. 1982. Major aspects of the vegetational history in the eastern Baltic coastal zone of Poland. Acta Palaeobotanica 22(1): 47-63.

Latałowa M. 1992. Man and vegetation in the pollen diagrams from Wolin Island (NW Poland). Acta Palaeobotanica 32(1): 123-249

Latałowa M. 1999a. Palaeohydrological reconstruction of the environmental conditions and economy in early medieval Wolin - against a background of the Holocene history of the landscape. Acta Palaeobotanica 39(2): 183-271.

Latałowa M. 1999b. Zmiany hydrologiczne wywołane przez czynnik klimatyczny i działalność człowieka zapisane w torfowisku Kołczewo i osadach dennych Jeziora Raczego. In: R.K. Borówka, Z. Młynarczyk, A. Wojciechowski (eds) Ewolucja geosystemów nadmorskich poludniowego Baltyku. Bogucki Wydawnictwo Naukowe, Poznań-Szczecin: 99-103. 
Łącka B., Starnawska E., Kuźniarski M. 1998. Mineralogy and geochemistry of the Younger Dryas sediments from Lake Gościąż. In: M. Ralska-Jasiewiczowa, T. Goslar, T. Madeyska, L. Starkel (eds) Lake Gościąż, Central Poland. A monography study, part 1. W. Szafer Institute of Botany, Polish Academy of Sciences, Kraków: 124-128.

Madeja J. 2012. Local Holocene vegetation changes and settlement history based on pollen analysis of Lake Kwiecko sediments, West-Pomeranian Lake District, NW Poland. Acta Palaeobotanica 52,1: 105-125.

Majdanowski S. 1950/51. Katalog jezior dorzecza Odry i rzek pobrzeża bałtyckiego między Odrą a Wisłą. Przegląd Geograficzny 23: 137-146.

Malkiewicz M. 2009. Analiza palinologiczna osadów organicznych stanowiska archeologicznego Święte 22. W: J. Affelski, M. Ignaczak, H. Machajewski, Z. Woźniak, D. Żychliński (eds) Opracowanie wyników ratowniczych badań archeologicznych na stanowisku $n r 22$ w Świętym (AZP 33-10/128), gm. Stargard, pow. stargardzki, woj. zachodniopomorskie. Pracownia Archeologiczno-Konserwatorska, Gniezno: 104-119.

Malkiewicz M. 2017. The vegetation in the light of palynological studies. In: T. Płonka, K. Kowalski (eds) Rusinowo. The symbolic culture of foragers in the late Palaeolithic and the early Mesolithic. University of Wrocław, Institute of Archaeology, Wrocław: 33-41.

Malkiewicz M., Tomaszewska K. 2009. Paleobotaniczny zapis zmian w holoceńskim środowisku przyrodniczym okolic Czarnowa (Pojezierze Zachodniopomorskie). Późnoglacjalne i holoceńskie zmian środowiska abiotycznego i ich zapis paleobotaniczny. Mater. Konf. 4 Pol. Konf. Paleobot. Czwartorzędu. 16-19.06.2009, Jeziorowskie. Wyd. PIG, Warszawa: 23-24.

Marks L. 2005. Pleistocene glacial limits in the territory of Poland. Przeglad Geologiczny 53,10/2: 988993.

Matuszewska A. 2019. Kultura pucharów lejkowatych na Nizinie Pyrzyckiej. In: M. Szmyt, P. Chachlikowski, J. Czebreszuk, M. Ignaczak, P. Makarowicz (eds) Od kujawskiego matecznika do stepów nadczarnomorskich. Studia z dziejów międzymorza baltycko-pontyjskiego. Instytut Archeologii UAM, Poznań: 371-384.

Matuszewska A., Szydłowski M. 2012. Megality Pomorza Zachodniego. Na tropie budowniczych tajemniczych grobowców $\mathrm{z}$ epoki kamienia. Wydawnictwo Zapol Dmochowski Sp., Szczecin: 1-92.

Mendyk Ł., Markiewicz M., Bednarek R., Świtoniak M., Gamrat W.W., Krześlak I., Sykuła M., Gersztyn L., Kupniewska A. 2016. Environmental changes of a shallow kettle lake cachment in a young glacial landscape (Sumowskie Lake catchment) North-Central Poland. Quaternary International 418: 116-131.

Meyers P.A. 1994. Preservation of elemental and isotopic source identification of sedimentary organic matter. Chemical Geology 114,3-4: 289302.

Michczyńska D.J., Starkel L., Nalepka D., Pazdur A. 2013. Hydrological changes after the last ice retreat in Northern Poland using radiocarbon dating. Radiocarbon 55,2/3: 1712-1723.

Migaszewski Z.M., Gałuszka A. 2007. Podstawy geochemii środowiska. Wydawnictwa NaukowoTechniczne, Warszawa.

Miotk-Szpiganowicz G. 1992. The history of the vegetation of Bory Tucholskie and the role of man in the light of palynological investigations. Acta Palaeobotanica 32(1): 39-122.

Noryśkiewicz A.M. 2014. Vegetation and settlement history as reflected by pollen analysis. In: W. Chudziak, R. Kaźmierczak (eds) The Island in Żótte on Lake Zarańskie. Early Medieval Gateway into West Pomerania. Wydawnictwo Naukowe UMK, Toruń: 367-560.

Nowaczyk B., Owsianny P.M. 2011. Morfologia I litologia glacjalnej Rynny Jezior Kuźnickich koło Piły. Landform Analysis 16: 133-138.

Okuniewska-Nowaczyk I., Sobkowiak-Tabaka I. 2014. Palynology and archaeology of Late Vistulian and early Holocene sites in Lubuskie Lake District, Western Poland. Studia Quaternaria 31,1: 39-50.

Okupny D., Fortuniak A., Tomkowiak J. 2013. Cechy denudacji $\mathrm{w}$ regionie łódzkim $\mathrm{w}$ późnym vistulianie w świetle chemicznych badań w osadach torfowiskowych. Acta Geographica Lodziensia 101: 89-99.

Okupny D., Rzepecki S., Borówka R.K., Forysiak J., Twardy J., Fortuniak A., Tomkowiak J. 2016. Factors influencing temporal changes in chemical composition of biogenic deposits in the middle Tążyna River Valley (Kuyavian Lakeland, central Poland). Geologos 22,2: 121-136.

Owsianny P.M., Nowaczyk B., Sobczyński T. 2011. Stratygraficzne zróżnicowanie wybranych cech geochemicznych osadów równin akumulacji biogenicznej przylegających do jezior Kuźniczek, Kuźnik Mały i Kuźnik Duży w Rezerwacie Przyrody Kuźnik. Landform Analysis 16: 139147.

Pawlikowski M., Ralska-Jasiewiczowa M., Schonborn W., Stupnicka E., Szeroczyńska K. 1982. Woryty near Gietrzwałd, Olsztyn Lake District, NE Poland - vegetational history and lake development during the last 12 years. Acta Palaeobotanica 22,1: 85-116.

Pelisiak A. 1991. Site catchment analysis: study about the Funnel Beaker Culture in Central Poland. $A r$ cheologia Polski 36,1/2: 73-92. 
Pędziszewska A., Święta-Musznicka J., Badura M., Matuszewska A., Czerniak L. 2019. Wczesnoneolityczne miejsce kultu w Nowym Objezierzu w świetle badań paleośrodowiskowych. Sympozjum Sekcji Paleobotanicznej Polskiego Towarzystwa Botanicznego, Polska Akademia Nauk Muzeum Ziemi w Warszawie: 37-39.

Pędziszewska A., Tylmann W., Witak M., Piotrowska N., Maciejewska E., Latałowa M. 2015. Holocene environmental changes reflected by pollen, diatoms, and geochemistry of annually laminated sediments of Lake Suminko in the Kashubian Lake District (N Poland). Review of Palaeobotany and Palynology 216: 55-75.

Piotrowski A., Sochan A. 2011. Szczegółowa mapa geologiczna Polski 1:50 000, arkusz Barlinek (347). Państwowy Instytut Geologiczny, Warszawa.

Pleskot K., Tjallingii R., Makohonienko M., Nowaczyk N., Szczuciński W. 2018. Holocene paleohydrological reconstruction of Lake Strzeszyńskie (western Poland) and its implications for the central European climatic zone. Journal of Paleolimnology 59(4): 443-459.

Płaza D.K., Forysiak J., Borówka R.K., Okupny D., Marosik P., Obremska M., Michczyńska D.J. 2013/2015. Aktywność osadnicza grup mezolitycznych na obszarze wydm w Aleksandrowie i jej zapis w osadach przyległego torfowiska Rąbień. Prace i Materiaty Muzeum Archeologicznego i Etnograficznego $w$ Lodzi, Seria Archeologiczna 46: 229-250.

Płóciennik M., Kruk A., Forysiak J., Pawłowski D., Mianowicz K., Elias S., Borówka R.K., Kloss M., Obremska M., Coope R., Krąpiec M., Kittel P., Żurek S. 2015. Fen ecosystem responses to water-level fluctuations during the early and middle Holocene in central Europe: a case study from Wilczków, Poland. Boreas 44: 721-740.

Ralska-Jasiewiczowa M. (ed.) 1989. Environmental changes recorded in lakes and mires of Poland durng the last 13,000 years. Acta Palaeobotanica 29.

Reimer P.J., Bard E., Bayliss A., Beck J.W., Blackwell P.G., Ramsey C.B., Buck C.E., Cheng H., Edwards R.L., Friedrich M., Grootes P.M., Guilderson T.P., Haflidason H., Hajdas I., Hatte C., Heaton T.J., Hoffmann D.L., Hogg A.G., Hughen K.A., Kaiser K.F., Kromer B., Manning S.W., Niu M., Reimer R.W., Richards D.A., Scott E.M., Southon J.R., Staff R.A., Turney C.S.M., van der Plicht J. 2013. Intcal 13 and Marine 13 radiocarbon age calibration curves $0-50,000$ years cal BP. Radiocarbon 55: 1869-1887.

Rodin L.E., Bazylević N.I. 1965. Dinamika organičeskogo veščestva i biologičeskij krugovorot zolnych elementov i azota $\mathrm{v}$ osnovnych tipach rastitelnosti ziemnogo šara. Izdatelstvo Nauka, Moskva-Leningrad.
Rydelek P. 2005. Genetyczne uwarunkowania przestrzennej zmienności zawartości węgla organicznego i siarki w obrębie torfowiska w dolinie rzeki Kurówki. Przegląd Geologiczny 53,8: 673676.

Rydelek P. 2011. Geneza i skład części mineralnych wybranych złóż torfów niskich Wysoczyzny Lubartowskiej. Woda - Środowisko - Obszary Wiejskie 11,2: 135-149.

Sawłowicz Z. 1993. Pyrite framboids and their development: a new conceptual mechanism. Geologische Rundschau 82: 148-156.

Sawłowicz Z. 2000. Framboids: from their origin to application. Prace Mineralogiczne 88: 1-80.

Selvaraj K., Lin B.Z., Lou J.Y., Xia L., Huang X.T., Chen C.T.A. 2016. Lacustrine sedimentological and geochemical records for the last 170 years of climate and environmental changes in southeastern China. Boreas 45,1: 165-179.

Siuchniński K. 1969. Klasyfikacja czasowoprzestrzenna kultur neolitycznych na Pomorzu Zachodnim, część I. Katalog źródeł archeologicznych. Szczecin.

Siuchniński K. 1972. Klasyfikacja czasowo-przestrzenna kultur neolitycznych na Pomorzu Zachodnim, część II. Opracowanie analityczne. Szczecin.

Słowiński M., Marcisz K., Płóciennik M., Obremska M., Pawłowski D., Okupny D., Słowińska S., Borówka R., Kittel P., Forysiak J., Michczyńska D.J., Lamentowicz M. 2016. Drought as a stress driver of ecological changes in peatland - A palaeoecological study of peatland development between $3500 \mathrm{BCE}$ and $200 \mathrm{BCE}$ in central Poland. Palaeogeography, Palaeoclimatology, Palaeoecology 461: 272-291.

Sobkowiak-Tabaka I., Pawłowski D., Milecka K., Kubiak-Martens L., Kostecki R., Janczak-Kostecka B., Goslar T., Ratajczak-Szczerba M. 2020. Multi-proxy records of Mesolithic activity in the Lubuskie Lakeland (western Poland). Vegetation History and Archaeobotany 29: 153-171.

Sochan A., Piotrowski A. 2004. Objaśnienia do Szczegółowej mapy geologicznej Polski 1:50 000, arkusz Jesionowo (307). Państwowy Instytut Geologiczny, Warszawa.

Solheim A.K., Globevnik L., Austnes K., Kristensen P., Moe S.J., Person J., Philips G., Poikane S., van de Bund W., Birk S. 2019. A new broad typology for rivers and lakes in Europe: Development and application for large-scale environmental assesments. Science of the Total Environment 697: 134043.

Stach A. 2003. Uwarunkowania i funkcjonowanie procesów denudacji chemicznej mikrozlewni na obszarze młodoglacjalnym. Wyd. Nauk UAM, Geografia 67: 1-212.

Starkel L., Michczyńska D.J., Krąpiec M., Margielewski W., Nalepka D., Pazdur A. 2013. Progress in 
the Holocene chrono-climatostratigraphy of Polish territory. Geochronometria 40: 1-21.

Staszak-Piekarska A., Rzodkiewicz M. 2015. Reconstruction of palaeoecological changes in Lake Łebsko on the basis of diatom analysis (the southern Baltic coast, Poland). Landform Analysis 29: 81-90.

Tobolski K. 1976. Przemiany klimatyczno-ekologiczne w okresie czwartorzędu a problem zmian we florze. Phytocoenosis. Biuletyn Fitosocjologiczny 5,3/4: 187-197.

Tobolski K. 1987. Holocene vegetational development based on the Kluki reference site in the Gardno-Łeba Plain. Acta Palaeobotanica 27,1: 179-222.

Tolksdorf J.F., Kaiser K. 2012. Holocene eolian dynamics in the European sand-belt as indicated by geochronological data. Boreas 41,3: 408-421.

Tribovillard N., Algeo T.J., Lyons T., Riboulleau A. 2006. Trace metals as paleoredox and productivity proxies: An update. Chemical Geology 232: 12-32.

Tudyka K., Bluszcz A., Kozłowska B., Pawlyta J., Michczyński A. 2015. Low level ${ }^{14} \mathrm{C}$ measurements in freshly prepared benzene samples with simultaneous ${ }^{214} \mathrm{Bi} /{ }^{214} \mathrm{Po}$ pairs counting for routine ${ }^{222} \mathrm{Rn}$ contamination correction. Radiation Measurements 74: 6-11.

Walker M., Head M.J., Berkelhammer M., Bjorck S., Cheng H., Cwynar L., Fisher D., Gkinis V., Long A., Lowe J., Newnham R., Rasmussen S.O., Weiss H. 2018. Formal ratification of the subdivision of the Holocene Series/Epoch 9Quaternary System/Period): two new Global Boundary Stratotype Sections and Points (GSSPs) and three stages/subseries. Episodes 41,1: 213-223.
Wesołowski S. 1996. Stan badań nad osadnictwem kultury łużyckiej Pomorza Zachodniego. In: L. Leciejewicz, E. Gringmuth-Dallmer (eds) Człowiek $i$ środowisko $w$ środkowym $i$ dolnym nadodrzu. Instytut Archeologii i Etnologii PAN, Wrocław: 81-96.

Wojciechowski A. 2000. Zmiany paleohydrologiczne w środkowej Wielkopolsce w ciągu ostatnich 12000 lat w świetle badań osadów jeziornych rynny kórnicko-zaniemyskiej. Wyd. Nauk. UAM, seria Geografia, 63.

Woszczyk M. 2011. Paleolimnologiczna interpretacja krzemionki biogenicznej - dyskusja na przykładzie wybranych jezior Niżu Polskiego. Badania Fizjograficzne, seria A, Geografia Fizyczna 62: 165-179.

Woszczyk M., Spychalski W. 2013. Fractionation of metals in the Sa1/2 sediment core from Lake Sarbsko (northern Poland) and its palaeolimnological implications. Chemical Speciation and Bioavailability 25: 235-246.

Żarczyński M., Wacnik A., Tylmann W. 2019. Tracing lake mixing and oxygenation regime using the $\mathrm{Fe} / \mathrm{Mn}$ ratio in varved sediments: 2000 year record of human-induced changes from Lake Żabińskie (NE Poland). Science of the Total Environment 657: 585-596.

Żurek S. 1986. Szybkość akumulacji torfu i gytii w profilach torfowisk i jezior Polski (na podstawie danych ${ }^{14} \mathrm{C}$ ). Przeglad Geograficzny 58,3: 459477.

Żurek S. 1987. Złoża torfowe Polski na tle stref torfowych Europy. Dokumentacja Geograficzna IGiPZ PAN 4: 1-84. 